\title{
Evaluation of the Impacts of Heat Exchanger Operation on Quality of Water Used as Heat Source and Sink
}

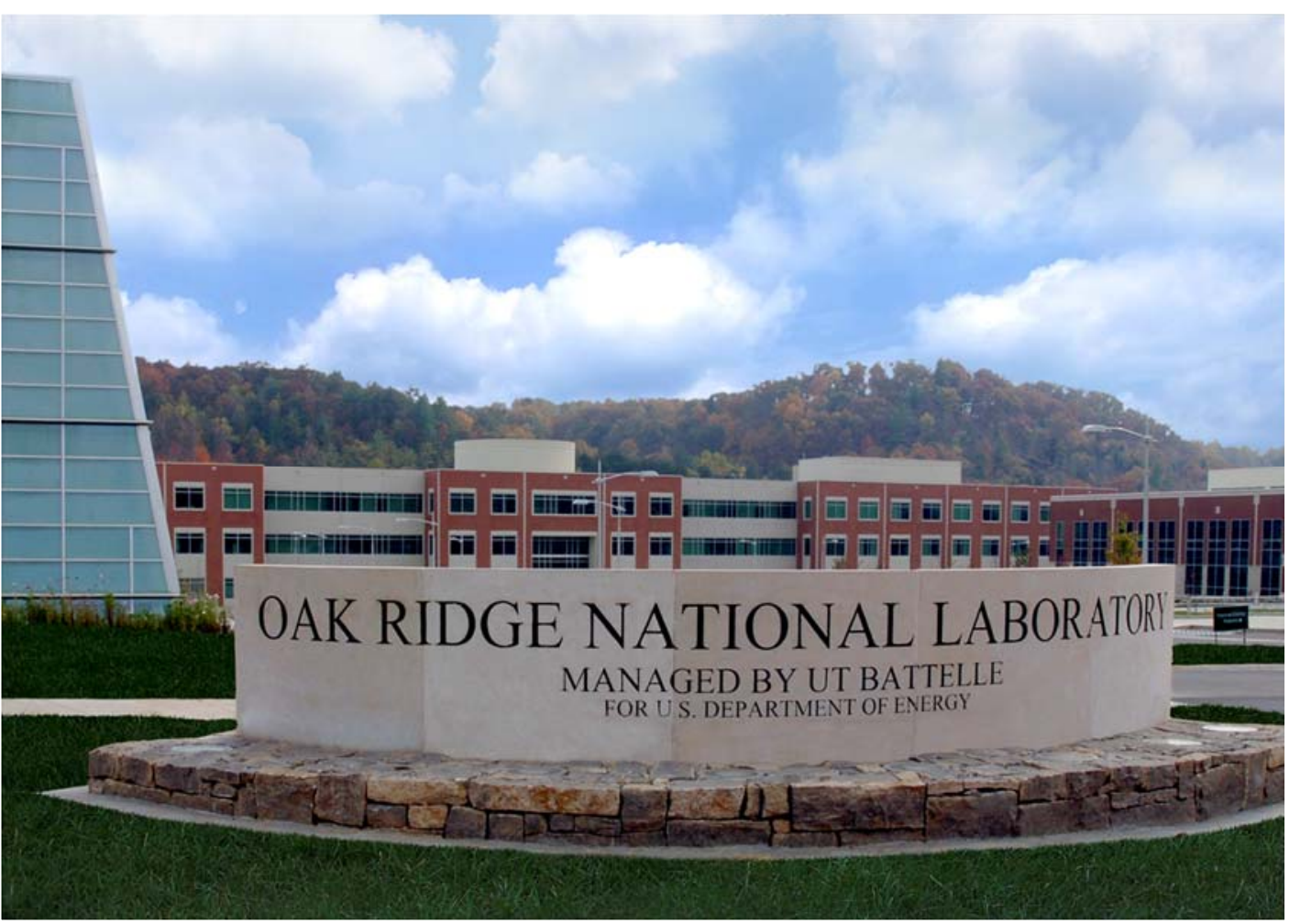

Ellen D. Smith

Xiaobing Liu

Approved for public release. Distribution is unlimited. 


\section{DOCUMENT AVAILABILITY}

Reports produced after January 1, 1996, are generally available free via US Department of Energy (DOE) SciTech Connect.

Website www.osti.gov

Reports produced before January 1, 1996, may be purchased by members of the public from the following source:

National Technical Information Service

5285 Port Royal Road

Springfield, VA 22161

Telephone 703-605-6000 (1-800-553-6847)

TDD 703-487-4639

Fax 703-605-6900

E-mail info@ntis.gov

Website http://classic.ntis.gov/

Reports are available to DOE employees, DOE contractors, Energy Technology Data Exchange representatives, and International Nuclear Information System representatives from the following source:

Office of Scientific and Technical Information

PO Box 62

Oak Ridge, TN 37831

Telephone 865-576-8401

Fax 865-576-5728

E-mail reports@osti.gov

Website http://www.osti.gov/contact.html

This report was prepared as an account of work sponsored by an agency of the United States Government. Neither the United States Government nor any agency thereof, nor any of their employees, makes any warranty, express or implied, or assumes any legal liability or responsibility for the accuracy, completeness, or usefulness of any information, apparatus, product, or process disclosed, or represents that its use would not infringe privately owned rights. Reference herein to any specific commercial product, process, or service by trade name, trademark, manufacturer, or otherwise, does not necessarily constitute or imply its endorsement, recommendation, or favoring by the United States Government or any agency thereof. The views and opinions of authors expressed herein do not necessarily state or reflect those of the United States Government or any agency thereof. 


\title{
EVALUATION OF THE IMPACTS OF HEAT EXCHANGER OPERATION ON QUALITY OF WATER USED AS HEAT SOURCE AND SINK
}

\author{
Ellen D. Smith \\ Environmental Sciences Division \\ Xiaobing Liu \\ Energy \& Transportation Science Division
}

Date Published: June 30, 2018

\author{
Prepared by \\ OAK RIDGE NATIONAL LABORATORY \\ Oak Ridge, Tennessee 37831-6283 \\ managed by \\ UT-BATTELLE, LLC \\ for the \\ US DEPARTMENT OF ENERGY \\ under contract DE-AC05-00OR22725
}





\section{CONTENTS}

Page

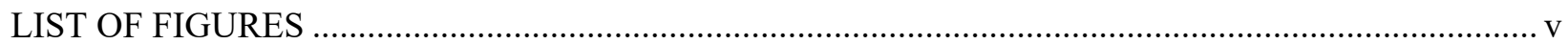

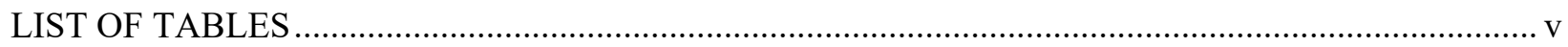

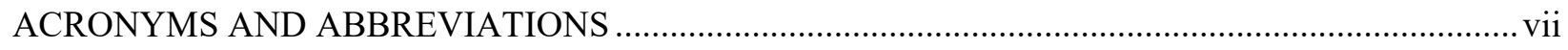

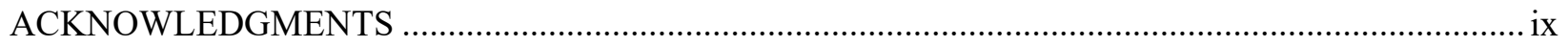

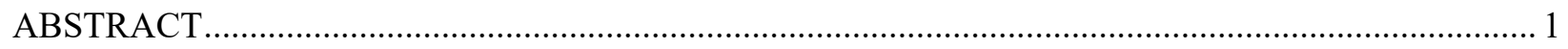

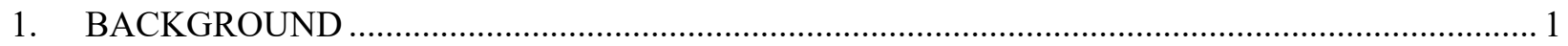

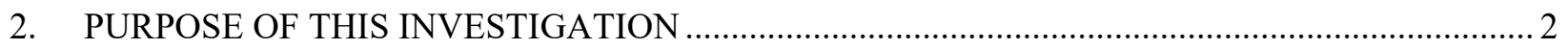

3. DATA PROVIDED FOR REVIEW OF WATER QUALITY IMPACTS OF THE HEAT

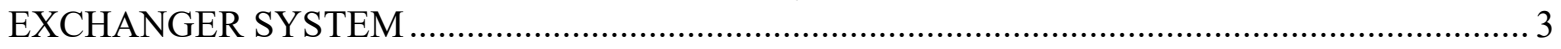

4. ORNL REVIEW OF ANALYTICAL METHODOLOGY ….............................................. 3

5. ORNL REVIEW OF WATER QUALITY MONITORING RESULTS …...................................... 4

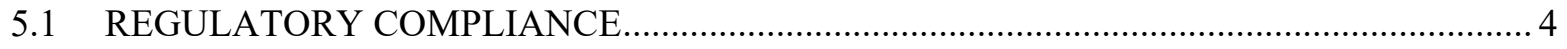

5.2 EFFECTS OF THE HEAT EXCHANGER SYSTEM ON WATER QUALITY...................... 5

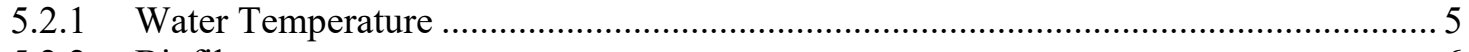

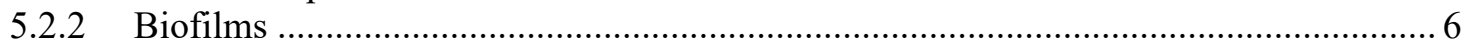

5.2.2.1 Context for biofilm measurements ......................................................... 6

5.2.2.2 Observations of biofilm formation ....................................................... 7

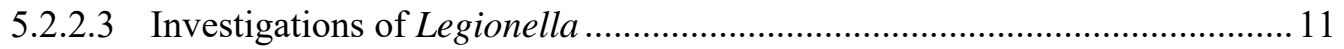

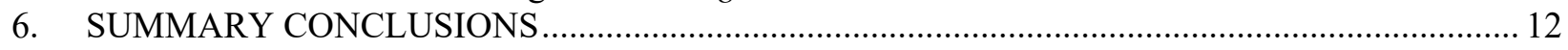

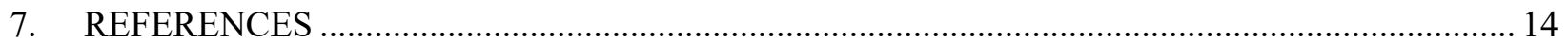

APPENDIX A. SUMMARY LIST OF ANALYTES REPORTED TO ORNL BY NYAW ................... A-1

APPENDIX B. METHODOLOGY DESCRIPTIONS PROVIDED TO ORNL BY NYAW .................. B-1 



\section{LIST OF FIGURES}

Page

Figure 1. ATP accumulation rates (mean of two samples) for biofilms vs. mean temperature recorded in sampling events in 2015 and 2016 during the period when the biofilm was forming.

\section{LIST OF TABLES}

Page

Table 1. Summary statistics for all reported metrics of biofilm formation in inflow and outflow

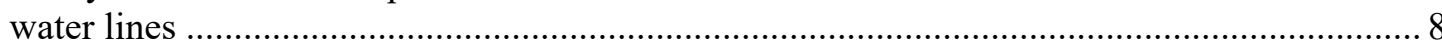

Table 2. HPC bacterial densities determined from biofilms formed during the cooling season................. 9

Table 3. ATP accumulation rates determined from biofilms formed during the cooling season................ 10 



\section{ACRONYMS AND ABBREVIATIONS}

$\begin{array}{ll}\text { ATP } & \text { adenosine triphosphate } \\ { }^{\circ} \mathrm{C} & \text { degrees Celsius } \\ \mathrm{CFU} & \text { colony forming unit } \\ { }^{\circ} \mathrm{F} & \text { degrees Fahrenheit } \\ \mathrm{ft} & \text { feet } \\ \mathrm{ft}^{2} & \text { square feet } \\ \mathrm{GHP} & \text { geothermal heat pump } \\ \mathrm{gpm} & \text { gallons per minute } \\ \mathrm{HPC} & \text { heterotrophic plate count } \\ \mathrm{MCL} & \text { maximum contaminant level } \\ \mathrm{mg} / \mathrm{L} & \text { milligrams per liter } \\ \mathrm{mL} & \text { milliliter } \\ \text { mm } & \\ \mathrm{MPN} & \text { square millimeters } \\ \mathrm{NYAW} & \text { most probable number } \\ \text { ORNL } & \text { New York American Water } \\ \text { PCR } & \text { Oak Ridge National Laboratory } \\ \text { qPCR } & \text { polymerase chain reaction } \\ \text { pg } & \text { quantitative PCR } \\ \text { VOCs } & \text { picograms } \\ \end{array}$





\section{ACKNOWLEDGMENTS}

American Water provided financial support for ORNL's independent review. Project direction and approval for public release of this report were provided by American Water personnel William Varley, VP \& Deputy COO, Carmen Tierno, President of New York American Water, Benjamin Stanford, Senior Director of Water Intelligence, and Matt Corson, Director of Environmental Compliance \& Stewardship. Numerous other individuals have contributed to the operation, testing, and analysis of the geothermal heat pump system at Buck Elementary School, and to writing reports and compiling data. Individuals who supported the review by providing information to ORNL, discussing the geothermal heat pump system and the analyses with the authors, and providing comments on drafts of this report included Patrick Jjemba, Richard Kern, Kendra Morris, and Michael Nofi. 



\begin{abstract}
To help inform future decisions about the subsequent uses of water that has served as a heat source and sink in the heat exchanger component of a geothermal heat pump system, ORNL performed an independent assessment of data characterizing the quality of water that had passed through a heat exchanger supporting a geothermal heat pump in a school building. Water supply to the heat exchanger is treated drinking water from a public water supply system that derives its water from a groundwater source. Water analyses and bacteriological measurements collected from heat exchanger inflow and outflow lines were supplied to ORNL for review. Data were compared with regulatory standards and inflow and outflow data were compared to identify changes occurring in the water resulting from its passage through the heat exchanger. Review of the data identified no conditions that would prevent the use of heat exchange outflow water for water supply. Inflow and outflow water quality conforms with applicable regulatory standards. There were no discernible differences between inflow and outflow water quality for any parameters other than water temperature and formation of heterotrophic bacterial biofilms. Changes in water temperature are an expected result of the operation of the heat exchanger system and do not by themselves affect the suitability of the water for human consumption or other domestic uses. Bacterial biofilm formation can be affected by water temperature, but the data did not show a consistent or statistically significant relationship between temperature parameters and biofilm formation, and the observations of biofilms formed in the heat exchanger water lines do not affect the suitability of the outflow water for water supply. Legionella, a bacterial genus that is detected in many different natural waters and water supplies and that has been associated with outbreaks of waterborne pathogenic disease, was detected at low levels in some biofilm samples from both inflow and outflow water lines, but comparison of inflow and outflow data shows that passage of water through the heat exchanger is not promoting the occurrence of Legionella in this system.
\end{abstract}

\title{
1. BACKGROUND
}

Geothermal heat pump (GHP) systems, also referred to as ground source heat pump systems, have been proven capable of producing large reductions in energy use, greenhouse gas emissions and peak period electricity demand in buildings while satisfying the requirements for space heating, space cooling, and domestic water heating (DOE 2016). GHPs utilize the ground, groundwater, or surface water as a heat source and sink. The primary barrier to widespread application of GHP systems is the high installation cost of the heat source and sink.

Utilizing water from the serving water utility's water main as the heat source and sink can dramatically reduce the cost of performance-neutral (or improved) GHP systems by eliminating the need for a dedicated bore field, thus enabling more widespread application and associated energy and environmental benefits. Section 3013 of the Energy Policy Act of 1992 directed the Secretary (of Energy) to "encourage States, municipalities, counties, and townships to consider allowing the installation of geothermal heat pumps, and, where applicable, and consistent with public health and safety, to permit public and private water recipients to utilize the flow of water from, and back into, public and private water mains for the purpose of providing sufficient water supply for the operation of residential and commercial geothermal heat pumps."

The purity and safety of the public water supply is the primary mission of water utilities and they are the entity that would be held responsible if GHP systems utilizing the flow of water from, and back into, public water mains somehow went awry and contaminated the public water supply. In view of the potential benefits to consumers and society of this type of system, one water utility installed a pilot project to assess this technology. 
In 2014/2015, New York American Water (NYAW), a unit of parent company American Water, retrofitted William L. Buck Elementary School with a GHP system using water from their water distribution lines as the heat source and sink. The school is a $40,000 \mathrm{ft}^{2}$ facility constructed in the mid 1950's in the village of Valley Stream in southwestern Nassau County, New York. NYAW is regulated by the New York State Public Service Commission. Valley Stream and surrounding communities are served by NYAW's Lynbrook Operations District. In this area, the water supply is from groundwater drawn from wells at depths ranging from 30 to $1,100 \mathrm{ft}$ with an average depth of $500 \mathrm{ft}$. NYAW Lynbrook Operations has wells in the Upper Glacial, Magothy, Jameco and Lloyd aquifers. According to NYAW personnel, water supplied in the area of the school is mostly derived from the Magothy aquifer (NYAW staff, personal communication in teleconference with ORNL staff on 19 January 2017). The source water is chlorinated for bacterial disinfection, treated with lime (calcium hydroxide) or caustic soda (sodium hydroxide) to raise $\mathrm{pH}$ and reduce corrosivity, and may also be filtered or treated with sodium silicate to control dissolved iron (NYAW 2016).

The pilot project at Buck Elementary School was supplied by a 4-inch water service line that delivered water at rates of 150 to 275 gallons per minute (gpm) to a food-grade stainless steel heat exchanger. On one side of the heat exchanger is the city water supplied from the water mains; on the other side is a recirculated mixture of water and propylene glycol that serves heat pumps throughout the school, providing a combined heating and cooling capacity of 133 tons (Lombardo 2015). The combination of the city water supply and the heat exchanger eliminated the need for a bore field, significantly reducing the cost of the GHP system.

In late February 2015 NYAW began operating this system as a pilot in order to collect water quality samples and record water supply temperature changes. During the pilot phase of this program, after the supply water passed through the heat exchanger, a portion of the water was discharged back to the aquifer via a diffusion well and the remainder was discharged to a sanitary sewer. If the water that has passed through the heat exchanger is found to have acceptable quality, NYAW intends to seek the necessary approvals to reconfigure the system to recirculate this water in its public water distribution system.

Throughout the pilot phase NYAW monitored water quality in the water lines both upstream and downstream of the heat exchanger. Water temperature and other key parameters were monitored continuously by the heat exchanger control system and the full range of required water quality parameters were analyzed every two weeks. In addition, NYAW conducted the pour plate methodology for detection of bacterial colonies in water samples (heterotrophic plate counts) and used a coupon system to measure biofilm formation and detect the presence of Legionella organisms. After Legionella was detected in one sample cultured from a biofilm, NYAW conducted additional coupon testing for several months and used a molecular analysis technique to enhance the detection of Legionella, quantify its presence, and identify any occurrences of the disease-causing species Legionella pneumophila.

\section{PURPOSE OF THIS INVESTIGATION}

To assist NYAW in evaluating the data from its pilot testing and to help inform future decisions about the subsequent uses of water that has served as a heat source and sink in the heat exchanger system, Oak Ridge National Laboratory (ORNL) performed an independent assessment of water quality data from the pilot testing to ascertain the impact of the heat exchanger system on water quality. 


\section{DATA PROVIDED FOR REVIEW OF WATER QUALITY IMPACTS OF THE HEAT EXCHANGER SYSTEM}

NYAW provided data obtained during the pilot phase to ORNL for evaluation and to support an independent assessment of the impacts of the heat exchanger system on water quality.

Data received were:

1. Tabulated results of field measurements at the time of sample collection of flow rate and inflow and outflow temperature, free chlorine residual, $\mathrm{pH}$, and pressure. Data were provided for several dates in early 2015 before the heat exchanger system was fully commissioned and for 41 sampling dates during full operation, from 19 March 2015 (shortly after the system was commissioned) and 28 September 2016.

2. Reports of results of laboratory analyses of water samples, including total dissolved solids, odor, turbidity, bacterial counts, hardness, purgeable volatile organic compounds (VOCs), inorganic compounds, and heterotrophic plate counts. Data were provided for two sampling dates before the heat exchanger system was fully commissioned and for 41 sampling dates during full operation. Analyses were performed by Pace Analytical.

3. Tabulated results of measurements of corrosion rates and biofilm formation on mild-steel corrosion coupons inserted in water lines for periods of approximately one month during the pilot phase testing of the heat exchanger system. In each test period, two coupons were placed in the inflow line and two coupons were placed in the outflow line. Twelve sets of data from coupon testing were provided, each including biofilm data from 4 coupons. For all but two of the test dates, corrosion rates were reported for both the inflow and outflow location; for two of the twelve testing dates corrosion rates were not determined for the coupons in the inflow line due to a problem with the testing equipment.

Complete lists of analytical parameters are provided in Appendix A. All of the data received from NYAW have been archived electronically and can be made available for review.

In addition, NYAW provided ORNL with a report entitled "Additional Evaluation of the Impacts of Heat Exchanger Operation on Distribution Water Quality" (Jjemba 2018; provided in Appendix B) describing the results of monitoring conducted in the period May through October 2017, including measurements of biofilm formation on coupons and molecular analyses to investigate the possible presence of bacteria of genus Legionella.

\section{ORNL REVIEW OF ANALYTICAL METHODOLOGY}

The methods used in the analyses provided by NYAW were reviewed to affirm their suitability for the purposes of this evaluation. Since the main objective of this evaluation is detection of changes in water quality resulting from passage through the heat exchanger, the most important criterion for acceptability of methodology is consistency of methodology between inflow and outflow water testing. Other important considerations include regulatory approval and scientific support for the methods.

Documentation supplied to ORNL indicates that Pace Analytical, which provided laboratory analyses for NYAW, has appropriate laboratory certifications and the analytical methods identified in the reports provided to NYAW by Pace Analytical are approved by federal and/or state environmental regulatory agencies. The Pace Analytical laboratory results reports indicate that samples were handled in accordance with standard protocols. All water samples were kept cool to the extent practicable and were delivered to the laboratory on the day of collection. There were no differences in sample handling or analytical 
methodology for inflow and outflow water samples. For the reasons discussed, the testing laboratory and its methods are suitable for this investigation.

The data qualifiers in the Pace Analytical results reports were reviewed for indications of data quality concerns that might affect the interpretability of results. Several of the reports included one or more notations of a calibration concern affecting a specific analyte. Most of these qualifiers were related to an organic compound, in which case the qualifier was applied to the analyses of both inflow and outflow samples. This means that the concern might affect the absolute value of the result for an analyte, but it should not affect the comparison between inflow and outflow data. Calibration concerns for inorganic analytes affected analysis of only the inflow or outflow sample, but in all but two instances (an analysis for barium and an analysis for sulfate) the inorganic analyte was one that was not detected in any sample during the entire study period. None of the data quality concerns noted in the Pace Analytical results sheets were judged to have the potential to adversely affect the interpretability of analytical results.

There are no regulatory requirements for analyses of biofilm formation on corrosion coupons or for the detection of Legionella in samples from potable water systems. NYAW provided a description (NYAW undated, provided in Appendix B) of the techniques used for the analysis of samples collected in 2015 and 2016. These analyses were performed in the company's own laboratory in Delran, New Jersey. Mild steel coupons were inserted in the inflow and outflow water lines for periods of approximately one month, allowing biofilms to form on the coupons. After the coupons were removed from the water lines, they were shipped overnight to the laboratory for analysis. At the laboratory, biofilms were scraped off the coupons and split into several portions for analysis. Rates of biofilm formation during the test period were determined by an assay of adenosine triphosphate (ATP; a biochemical indicator of biological activity) on a portion of the biofilm. Another portion of the biofilm was spread plated on R2A agar (Reasoner's 2A agar; a formulation for culturing heterotrophic bacteria found in water); colonies were counted after a one-week incubation. A third portion of the biofilm was cultured and tested for Legionella organisms. As documented in "NYAWC Geothermal Project Materials and Methods" (NYAW undated), these methodologies are based on scientific literature and standard methods. The same methods were used for analyses of inflow and outflow samples. Therefore, these analyses are suitable as a basis for comparing biofilm formation in inflow and outflow water.

As described above, review of analytical methodologies found that the analyses performed by or for NYAW were suitable for the review.

\section{ORNL REVIEW OF WATER QUALITY MONITORING RESULTS}

\subsection{REGULATORY COMPLIANCE}

Water quality results for both inflow and outflow water were found to meet both U.S. EPA and New York State regulatory standards for drinking water quality, with the exceptions of several exceedances of aesthetics-based secondary standards. Exceedances were observed in (1) several measurements for iron and manganese in both inflow and outflow water and (2) a single event when chlorine odor in both inflow and outflow water exceeded the threshold for odor. Neither of these exceedances is related to a potential public health concern and (because they occurred in both inflow and outflow water) neither is attributable to the heat exchanger. The U.S. EPA drinking water criteria for these parameters are among a set of nonmandatory secondary standards related to aesthetic considerations (not health). New York State regulations for public water supplies do include enforceable standards for iron, manganese, and odor, but review of the regulations indicates that the exceedances of regulatory thresholds reported for heat 
exchanger inflow and outflow water would not be considered violations of New York State regulations for public water supplies. ${ }^{1}$

\subsection{EFFECTS OF THE HEAT EXCHANGER SYSTEM ON WATER QUALITY}

Examination of the data from inflow and outflow monitoring found no discernible differences between inflow and outflow water quality for any parameters other than (1) water temperature and (2) biofilm formation. Concentrations of dissolved substances, including chlorine residual concentrations, did not change between inflow and outflow. The two topics of water temperature and biofilm formation are discussed in the following subsections.

\subsubsection{Water Temperature}

Water temperature is the only measured water quality parameter that was unmistakably affected by the operation of the heat exchanger system. Changes in water temperature were an expected result of the use of water in the system as a heat source and sink.

Additionally, although groundwater sources typically maintain constant temperature throughout the year (about $55^{\circ} \mathrm{F}$, equivalent to about $13{ }^{\circ} \mathrm{C}$, on Long Island), the temperature of inflow to the heat exchanger system was observed to vary seasonally. This seasonal variation is attributable to heat gain and loss within the water distribution system. New York American Water personnel informed ORNL that the company's water mains in the Lynnbrook area are typically at depths of about 3 to $4 \mathrm{ft}$ below ground surface. At this depth, seasonal changes in air temperature can be expected to affect soil temperatures. Periods of storage in aboveground tanks may also cause water temperatures to begin to equilibrate with air temperature. Inflow water temperatures reported at the time of sampling events (sampling occurred as early as 9:00 a.m. and as late as 1:40 pm) ranged from $10.0^{\circ} \mathrm{C}$ in June 2017 to $17.6^{\circ} \mathrm{C}$ in August 2016 .

Operation of the heat exchanger reduces outflow water temperature during heating operation and increases outflow water temperature during cooling operation. Geothermal heat pump systems can shift between heating and cooling mode with fluctuations in conditions including outdoor air temperature and building occupancy, and different modes can exist simultaneously in different parts of a building. Inspection of temperature data, including records of temperature at 15-minute intervals from the heatexchanger control system (supplied by New York American Water for some months of system operation) indicates that outflow water temperatures were generally lower than inflow temperatures from November through April, indicating that the system was predominantly operating in heating mode, and were generally higher than inflow temperatures from June through September, indicating that the system was predominantly operating in cooling mode. Water temperature data suggest that the months of May and

\footnotetext{
${ }^{1}$ For iron and manganese, the state regulations specify maximum contaminant levels (MCLs) of $0.3 \mathrm{mg} / \mathrm{L}$ for each of these elements and provide that if both iron and manganese are present, the total concentration of both should not exceed $0.5 \mathrm{mg} / \mathrm{L}$, but higher levels [up to $1.5 \mathrm{mg} / \mathrm{L}$ ] "may be allowed by the State when justified by the supplier of water" (New York State Department of Health, Drinking Water Regulations, Part 5, Subpart 5-1, Public Water Systems - Tables). The highest combined concentration of iron and manganese measured in the heat exchanger system was $0.94 \mathrm{mg} / \mathrm{L}$. NYAW's public water quality report (New York American Water, 2016) indicates that the state has allowed iron and manganese levels in the company's Lynnbrook Operations to exceed the $0.5-\mathrm{mg} / \mathrm{L}$ limit due to high natural levels of iron and manganese in the system's water source; treatment measures are employed to filter out iron and sequester iron that remains in solution to reduce its adverse effects. For odor, a single occurrence of excessive odor would not be treated as a violation; after an analytical result exceeds the MCL, the state regulations call for follow-up sampling and analysis to determine whether a violation has occurred (New York State Department of Health, Drinking Water Regulations, Part 5, Subpart 5-1, Public Water Systems - Tables). Accordingly, the exceedances of regulatory thresholds would not be considered violations of New York State regulations for public water supplies.
} 
October were transitional for the system, which shifted between heating mode and cooling mode on different days and different times of the same day. (On some spring and fall days, temperature data show that the system was in cooling mode during the daytime hours when the school was occupied, but at night it was in heating mode.)

During heating season, the lowest outflow water temperature measured at the time of sample collection was $8.5^{\circ} \mathrm{C}$, recorded in February 2016, and the largest temperature differential between inflow and outflow samples was a reduction of $2.3^{\circ} \mathrm{C}$, recorded in December 2015. During cooling season, the highest outflow water temperature measured at the time of sample collection was $21.3^{\circ} \mathrm{C}$, recorded in September 2015, and the largest temperature differential was an increase of $4.3{ }^{\circ} \mathrm{C}$, recorded on two occasions in June and July 2016.

Comparison of temperatures measured at the time of sample collection with records of temperature at 15minute intervals from the heat-exchanger control system suggests that measurements at the time of sample collection may not be representative of average conditions in the system, particularly during the cooling season. Cooling-season outflow water temperatures and temperature differentials measured at the time of sample collection (typically mid-to-late morning) are higher than the averages for that same full day. For example, on 28 September 2016, the inflow and outflow water temperatures measured at the time of sample collection were 15.0 and $17.8^{\circ} \mathrm{C}$, respectively, comparable to the values of 15.2 and 17.5 ${ }^{\circ} \mathrm{C}$ recorded at the same time by the control system, while 24 -hour average temperatures for the same date were 15.1 and $16.2^{\circ} \mathrm{C}$. Higher-than-average temperature differentials at the time of sample collection are attributable to the time of day when sampling occurred, because daytime air temperatures usually exceed the 24-hour average and because building occupancy at the time of sample collection contributes to the cooling load.

There are no regulatory criteria for water temperature in a public water supply. Unusually high or low temperatures might, however, affect customer satisfaction. Notably, in surveys and taste tests, Americans have been found to express a preference for drinking water at cold temperatures; subjects in experiments by Zellner et al. (1988) strongly preferred cold tap water at $0-5^{\circ} \mathrm{C}$ over tap water served at room temperature of $20-25^{\circ} \mathrm{C}$. Although water temperature can affect odor perception at temperatures above the room temperature range (Whelton and Dietrich 2004) and can affect taste perception of soluble substances such as sugar, salt, and acid, the preference for drinking cold tap water is attributed to psychological factors, not to sensory characteristics of the water (Zellner et al. 1988, Green 1993). In anticipation of returning heat exchanger outflow water to its Lynnbrook water distribution system, NYAW has done a modeling evaluation of operational measures to ensure that the temperature of water delivered to consumers would not increase by more than $3{ }^{\circ} \mathrm{C}$ as a result of passage through the heat exchanger system (Jjemba 2018).

\subsubsection{Biofilms}

\subsubsection{Context for biofilm measurements}

The biofilm measurements were part of a larger suite of observations of bacterial water quality. The investigations included measurements of three categories of bacteria:

1. Escherischia coli and total coliform bacteria. E. coli and total coliform bacteria are monitored and regulated as indicators of possible contamination, particularly fecal contamination.

2. Heterotrophic bacteria, a broad category that includes all bacteria that utilize organic carbon. The heterotrophic bacteria detected in water testing are sometimes referred to as "heterotrophic plate count bacteria" (HPC bacteria) to identify them as the subset of heterotrophic bacteria that are isolated and cultured by the set of methods used for determining a "heterotrophic plate count." While certain heterotrophic bacteria can be pathogenic, HPC bacteria and HPC counts have not 
been found to be relevant to human health risk (except possibly for severely immunocompromised individuals) and there are no health-based standards for HPC bacteria in drinking water (Allen et. 2004, Chowdhury 2012). Heterotrophic bacterial biofilms are of interest in water distribution systems primarily because of concerns such as their potential role in pipe corrosion, the possibility that biofilms on pipe walls could harbor pathogenic organisms, and aesthetic concerns related to taste, odor, and discoloration of water or plumbing fixtures (LeChevallier $1999^{2}$, Chowdhury 2012). The only U.S. or New York regulatory criterion for HPC bacteria is a criterion intended to ensure that the presence of heterotrophic bacteria will not interfere with detection of coliform bacteria.

3. Legionella, a bacterial genus that occurs in both natural waters and water distribution systems and that has been associated with outbreaks of waterborne pathogenic disease.

All bi-weekly water samples were tested and found to be negative for both E. coli and total coliform bacteria. All but 7 of the 78 heterotrophic plate counts (also known as "standard plate counts") for biweekly water samples found "less than" values of $<1$ or $<2$ for the "most probable number" of colonyforming units per milliliter of water $(\mathrm{MPN} / \mathrm{mL})$; the other 7 samples returned values of 2 to $6 \mathrm{MPN} / \mathrm{mL}$. These counts are very low. For context, for public water systems supplied by surface water or groundwater that is under surface water influence, New York regulations specify a heterotrophic plate count result of 500 colonies per milliliter or less. This criterion is intended to ensure that the presence of other heterotrophic bacteria will not interfere with detection of coliform bacteria (Allen et al. 2004). Bacterial counts typically are very low in water supplies obtained from groundwater, such as the NYAW Lynnbrook system.

\subsubsection{Observations of biofilm formation}

Biofilm measurements were obtained during the initial testing period in 2015-2016 and also from May 2017 (when the biofilm samples that were retrieved had been in the place for 8 months instead of the typical 1 month) through October 2017. Results of biofilm measurements from the heat-exchanger water lines are highly variable, probably due to factors such as the diversity of the organisms that could be present. As shown in Table 1, the standard deviations for measurements of both ATP assay (ATP accumulation rate) and plate count (HPC density) are larger than the mean values.

Results of measurements of biofilm formation were compared with values reported in other published studies of bacterial biofilms in water systems. The values measured in the heat exchanger lines are low in comparison with published values reported from other studies of bacterial biofilms, although it should be noted that results of different studies may not be directly comparable because results may be affected by methodological differences. A 15-month investigation of the effects of water characteristics on biofilm formation in 26 U.S. drinking water supply systems (LeChevallier et al. 2015) ${ }^{2}$ used an ATP assay similar to the one in this study and measured biofilm formation rates that ranged from near zero to more than $2.5 \mathrm{pg} / \mathrm{mm}^{2}-\mathrm{d}$, with a mean value of $0.074 \mathrm{pg} / \mathrm{mm}^{2}-\mathrm{d}$. The measurements from the heat-exchanger study are in the low end of the ranges found in the published water supply study. The mean value reported for all samples from inflow and outflow water lines for the Buck Elementary School heat-exchanger system was an order of magnitude lower than the mean in the water supply study, at $0.0083 \mathrm{pg} / \mathrm{mm}^{2}-\mathrm{d}$.

\footnotetext{
${ }^{2}$ American Water company personnel were among the authors of this study.
} 
Table 1. Summary statistics for all reported metrics of biofilm formation in inflow and outflow water lines

\begin{tabular}{|c|c|c|c|c|}
\hline & \multicolumn{2}{|c|}{ Inflow biofilm metrics } & \multicolumn{2}{|c|}{ Outflow biofilm metrics } \\
\hline & $\begin{array}{l}\text { ATP accumulation } \\
\text { rate }\left(\mathrm{pg} / \mathrm{mm}^{2}-\mathrm{d}\right)\end{array}$ & $\begin{array}{l}\text { HPC density } \\
\left(\mathrm{CFU} / \mathbf{m m}^{2}\right)\end{array}$ & $\begin{array}{c}\text { ATP accumulation rate } \\
\left(\mathrm{pg} / \mathrm{mm}^{2}-\mathrm{d}\right)\end{array}$ & $\begin{array}{l}\text { HPC density } \\
\left(\text { CFU/mm } \mathbf{m}^{2}\right)\end{array}$ \\
\hline Mean & 0.010 & 882 & 0.006 & 968 \\
\hline $\begin{array}{l}\text { Standard } \\
\text { deviation }\end{array}$ & 0.026 & 1856 & 0.008 & 2032 \\
\hline
\end{tabular}

In general, bacterial growth rates increase with increasing temperature, and the temperature $15^{\circ} \mathrm{C}$ has been suggested as a threshold of interest for bacterial growth in water supplies. Studies of water supply systems have found that the potential for occurrence of coliform bacteria is significantly higher when water temperatures exceed $15{ }^{\circ} \mathrm{C}$ (LeChevallier 1999). ${ }^{2}$ Also, the investigation of the effects of water characteristics on biofilm formation in $26 \mathrm{U}$.S. water-supply systems identified $15^{\circ} \mathrm{C}$ as a threshold water temperature for biofilm formation (LeChevallier et al., 2015). ${ }^{2}$ Below this temperature, rates of biofilm formation were consistently very low (the study reported a mean ATP accumulation rate of 0.00426 $\mathrm{pg} / \mathrm{mm}^{2}$-d for water less than $15^{\circ} \mathrm{C}$ ), but a substantial fraction of observations for water above this temperature had significantly elevated rates of biofilm formation (the study reported a mean ATP accumulation rate of $0.1035 \mathrm{pg} / \mathrm{mm}^{2}$-d for water above $15^{\circ} \mathrm{C}$ ). With this background, the biofilm data from the heat exchanger study were examined for indications of a relationship between biofilm formation, water temperature, and temperature changes resulting from the heat exchanger, including effects of temperature above or below $15^{\circ} \mathrm{C}$.

For evaluation of whether increased water temperatures resulting to cooling-season operation of the heat exchanger affected biofilm formation, the months of May through October were identified as approximating the cooling season. Available water temperature data from these months indicate that for at least part of the period when biofilms were forming inflow water temperatures were above $15^{\circ} \mathrm{C}$ and the temperature of water increased after passing through the heat exchanger system. Data from biofilm samples that substantially formed during these months were examined for differences between inflow and outflow values. Examination of the measurements of HPC density from biofilms from inflow and outflow water lines (Table 2) suggests a possible trend toward higher values in the outflow lines during the cooling season. Although the data in Table 2 suggest a tendency toward higher HPC densities in biofilms formed in outflow water during the cooling season, because the data are highly variable and the differences between outflow and inflow values are not statistically significant (differences between means do not approach thresholds for statistical significance). Also, it is interesting to note that the highest values of HPC density observed during the study were reported from samples collected from both inflow and outflow lines in March 2016, when the system had been operating in heating mode and water temperatures were well below $15^{\circ} \mathrm{C}$.

Measurements by ATP assay, which are based on biochemical indicators of bacterial activity, may have greater reproducibility than measurements based on counting bacterial colonies. Duda et al. (2015) reported good correlation between HPC plate counts and ATP assays on water samples. They observed that ATP assays of water samples showed less variability than HPC plate counts. As with HPC density, examination of biofilm accumulation rates for inflow and outflow biofilm samples formed during the cooling season suggests a possible tendency toward higher values in outflow water lines (Table 3 ), but the differences are not statistically significant (differences between means do not approach thresholds for statistical significance). 
Table 2. HPC bacterial densities determined from biofilms formed during the cooling season

\begin{tabular}{|c|c|c|}
\hline \multirow{2}{*}{ Biofilm Collection Date } & \multicolumn{2}{|c|}{ HPC density $\left(\mathrm{HPC} / \mathrm{mm}^{2}\right)$} \\
\hline & Inflow Line & Outflow Line \\
\hline \multirow{2}{*}{3 September 2015} & 17 & 30 \\
\hline & 24 & 55 \\
\hline \multirow{2}{*}{8 October 2015} & 0 & 0 \\
\hline & 1 & 118 \\
\hline \multirow{2}{*}{9 November 2015} & 2 & 26 \\
\hline & 4 & 125 \\
\hline \multirow{2}{*}{15 June 2016} & 209 & 242 \\
\hline & 314 & 1864 \\
\hline \multirow{2}{*}{14 July 2016} & 413 & 365 \\
\hline & 503 & 581 \\
\hline \multirow{2}{*}{24 August 2016} & 1232 & 1616 \\
\hline & 1357 & 1776 \\
\hline \multirow{2}{*}{28 September 2016} & 240 & 121 \\
\hline & 435 & 412 \\
\hline \multirow{2}{*}{22 June 2017} & 30 & 200 \\
\hline & 41 & 310 \\
\hline \multirow{2}{*}{31 July 2017} & 290 & 71 \\
\hline & 770 & 690 \\
\hline \multirow{2}{*}{30 August 2017} & 38 & 140 \\
\hline & 1300 & 770 \\
\hline \multirow{2}{*}{10 October 2017} & 480 & 350 \\
\hline & 660 & 830 \\
\hline Mean & 380 & 486 \\
\hline Standard Deviation & 428 & 557 \\
\hline \multicolumn{3}{|c|}{$\begin{array}{l}\text { Note: Two coupons were placed in each water line during each sampling period. } \\
\text { HPC densities determined for the individual biofilm samples are reported } \\
\text { separately. HPC bacterial densities were not determined for biofilm samples } \\
\text { collected on } 6 \text { August } 2015 \text {. }\end{array}$} \\
\hline
\end{tabular}

To assess whether biofilm accumulation rates in this study were increased by higher water temperature, all accumulation rates determined from ATP assays on samples collected in 2015 and 2016 were plotted against the average temperature in the time period when the biofilm was forming, as shown in Figure 1 (temperatures in this graph were determined as the mean of the temperatures at the times when water samples were collected). Figure 1 illustrates that there is no observable relationship between biofilm formation rate and temperature. It is interesting to note that the highest observed ATP accumulation rate was from a biofilm (collected in December 2015) that formed in an inflow water line during a period when water temperature was below $15{ }^{\circ} \mathrm{C}$. 
Table 3. ATP accumulation rates determined from biofilms formed during the cooling season

\begin{tabular}{|c|c|c|}
\hline \multirow{2}{*}{ Biofilm Collection Date } & \multicolumn{2}{|c|}{ ATP accumulation rate $\left(\mathrm{pg} / \mathrm{mm}^{2}-\mathrm{d}\right)$} \\
\hline & Inflow Line & Outflow Line \\
\hline \multirow{2}{*}{6 August 2015} & 0.0005 & 0.0017 \\
\hline & 0.0045 & 0.0071 \\
\hline \multirow{2}{*}{3 September 2015} & 0.0004 & 0.0003 \\
\hline & 0.0006 & 0.0004 \\
\hline \multirow{2}{*}{8 October 2015} & 0.0048 & 0.0048 \\
\hline & 0.0050 & 0.0110 \\
\hline \multirow{2}{*}{9 November 2015} & 0.0014 & 0.0001 \\
\hline & 0.0016 & 0.0002 \\
\hline \multirow{2}{*}{15 June 2016} & 0.00285 & 0.00035 \\
\hline & 0.00311 & 0.02705 \\
\hline \multirow{2}{*}{14 July 2016} & 0.00384 & 0.00408 \\
\hline & 0.00441 & 0.00762 \\
\hline \multirow{2}{*}{24 August 2016} & 0.00091 & 0.00055 \\
\hline & 0.00186 & 0.00629 \\
\hline \multirow{2}{*}{28 September 2016} & 0.00374 & 0.00333 \\
\hline & 0.00514 & 0.00570 \\
\hline \multirow{2}{*}{22 June 2017} & 0.003 & 0.003 \\
\hline & 0.005 & 0.005 \\
\hline \multirow{2}{*}{31 July 2017} & 0.007 & 0.002 \\
\hline & 0.007 & 0.015 \\
\hline \multirow{2}{*}{30 August 2017} & 0.008 & 0.004 \\
\hline & 0.029 & 0.019 \\
\hline \multirow{2}{*}{10 October 2017} & 0.009 & 0.004 \\
\hline & 0.015 & 0.015 \\
\hline Mean & 0.0053 & .0061 \\
\hline Standard Deviation & 0.0059 & .0067 \\
\hline
\end{tabular}

Note: Two coupons were placed in each water line during each sampling period. HPC densities determined for the individual biofilm samples are reported separately. 


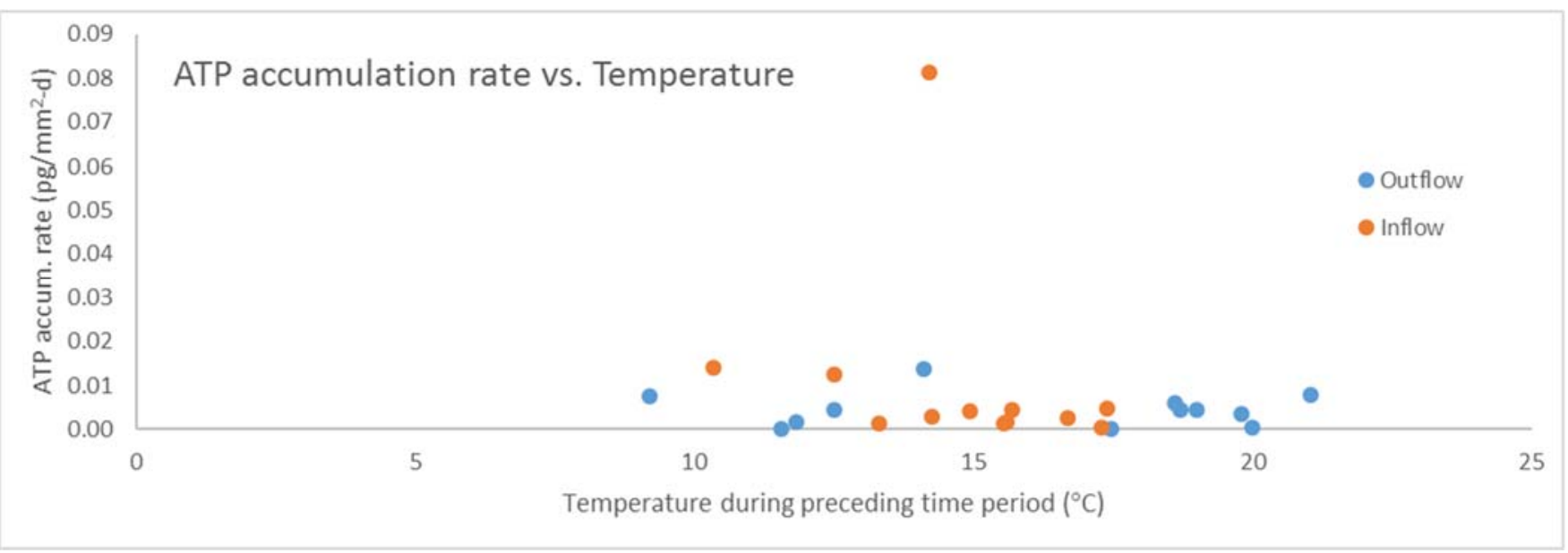

Figure 1. ATP accumulation rates (mean of two samples) for biofilms vs. mean temperature recorded in sampling events in 2015 and 2016 during the period when the biofilm was forming.

\subsubsection{Investigations of Legionella}

Legionella was detected in one biofilm sample during the initial testing period in 2015 and 2016. The sample was from a biofilm collected from the outflow line on 6 August 2015. Legionella is widely distributed in waters, typically at very low levels, and has been found in biofilms in water distribution systems. Filtration and disinfection of water supplies do not prevent the growth of Legionella, but this organism grows slowly and is difficult to culture. The significance of isolated observations of Legionella is uncertain. Disease outbreaks result from inhalation of Legionella in water droplets, and have been associated with cooling towers, hot tubs, shower heads, and recirculating hot water systems. Studies have found that Legionella does not proliferate except in the presence of protozoa, particularly amoebae (Committee on Public Water Supply Distribution Systems 2006).

To determine whether Legionella is present in the system and evaluate the significance of the finding, NYAW conducted additional coupon testing on five sets of coupon samples collected between May and October 2017 (a total of twenty samples, including two from the inflow line and two from the outflow line, collected on each of five dates). Collection and testing of biofilm samples in 2017 followed the same methodologies used for samples collected in 2015-2016, with the addition of quantitative polymerase chain reaction (qPCR) methodology to evaluate the presence of Legionella bacteria. Quantitative PCR has been demonstrated to be more effective at detecting Legionella than cell culture, thus reducing the potential for false negative results, and it enables quantification of the presence of this microorganism (Whiley and Taylor 2016; Collins et al. 2017). This methodology does, however, introduce a potential for false positives, as it does not distinguish whether detected DNA is from viable living Legionella or from dead or nonviable organisms (Whiley and Taylor 2016). Detection of Legionella in environmental samples using qPCR has been described as a widely accepted method that is growing in popularity (Collins et al. 2017).

The methodology for the Legionella investigation is described in reports provided to ORNL by NYAW (Jjemba 2018; Morris 2018; see Appendix B). DNA was extracted from a biofilm sample using a commercially available kit, eluted with water to a final volume of $50 \mathrm{uL}$, and amplified using rRNA specific primers targeting the variable 23S-5S ribosomal intergenic spacer region of Legionella, applying a technique described by Grattard et al. (2006). Quantification was conducted against a standard curve established from analysis of ten-fold dilutions of L. pneumophila strain Philadelphia 1, using methods based on published literature. Genetic sequences were evaluated against a National Center for Biotechnology Information database to determine their identity, including differentiating the species $L$. 
pneumophila. The great majority of Legionella infections are attributed to species L. pneumophila, although other species of Legionella are also capable of causing human infection, particularly in immunocompromised individuals (Grattard et al. 2006, Yang et al. 2010). Because the qPCR methodology used by NYAW followed published methodologies, and the same methods were used for biofilm samples from inflow and outflow water lines, the analyses are judged to be suitable as a basis for comparative evaluation of Legionella presence in inflow and outflow water lines.

Legionella was not found in cultures from any of the samples obtained in 2017, but DNA markers for Legionella were detected in nine of ten samples from inflow lines (at least one sample from every sampling date) and five of ten samples from outflow lines (at least one sample from four of the five sampling dates). For both inflow and outflow lines, quantification indicated the presence of 40 to 119 gene copies per $\mathrm{mm}^{2}$ coupon surface in samples that had Legionella markers. Sequencing of material from these fourteen samples confirmed the presence of Legionella in three samples and provided uncertain results for three samples; sequencing failed to identify Legionella in the remaining samples. Five inflow samples collected on four dates (May, July, August, and October) had identified or uncertain presence of Legionella and one outflow sample collected in June had identified or uncertain presence of Legionella. L. pneumophila, the species implicated in the large majority of human disease cases, was identified in just one of the positive samples (one inflow sample collected in October, in a sample that had 40 gene copies per $\mathrm{mm}^{2}$ ); the other five identifications were of undetermined species of Legionella.

The detection of markers for Legionella in a large fraction of samples is generally consistent with the findings of other studies that have used qPCR to test water samples for this organism and have found it in a large fraction of various types of natural waters and water supplies that are tested (Whiley and Taylor 2016; Collins et al. 2017). While Legionella is a cause for public-health concern, detection of this ubiquitous organism at low levels can be interpreted as indicating only low risk (Whiley and Taylor 2016). Its presence in both inflow and outflow biofilm samples from the heat exchanger study, including its presence in more inflow samples than outflow samples, supports a conclusion that passage of water through the heat exchanger is not promoting the occurrence of Legionella in this system.

\section{SUMMARY CONCLUSIONS}

In summary, water quality data supplied by New York American Water were found to be suitable for the purposes of the evaluation. Data were compared with regulatory standards and inflow and outflow data were compared to identify changes occurring in the water as a result of its passage through the heat exchanger. Review of the data identified no conditions that would prevent the use of heat exchange outflow water for water supply. Specifically:

1. Water quality conforms with applicable regulatory standards.

2. There are no discernible differences between inflow and outflow water quality for any parameters other than water temperature and growth of heterotrophic bacteria in biofilms. The observed differences in bacterial growth in biofilms are inconsistent, and differences between inflow and outflow are not statistically significant.

3. Changes in water temperature are an expected result of the operation of the heat exchanger system and do not by themselves affect the suitability of the water for human consumption.

4. Bacterial biofilm formation can be affected by water temperature, but the data did not show a consistent or statistically significant relationship between temperature parameters and biofilm formation, and all measured values of biofilm formation were very low. Heterotrophic bacterial biofilms are common in water distribution systems. They are not normally a source of concern for human health and are not subject to regulatory standards. Accordingly, the observations of 
biofilms formed in the heat exchanger water lines do not affect the suitability of the outflow water for water supply.

5. Legionella, a bacterial genus that is found in many waters and that has been associated with outbreaks of waterborne pathogenic disease, was detected in biofilms retrieved from both inflow and outflow water lines. Its presence in both inflow and outflow biofilm samples from the heat exchanger study supports a conclusion that passage of water through the heat exchanger is not promoting the occurrence of Legionella in this system. Moreover, although the potential presence of Legionella in a water supply cannot be dismissed as a public health concern, this organism has been detected in many water sources and water supplies, so its detection at low levels in this investigation does not indicate any particular risk. 


\section{REFERENCES}

Allen, Martin J., Stephen C. Edberg, and Donald J. Reasoner. 2004. Heterotrophic plate count bacteria What is their significance in drinking water? International Journal of Food Microbiology 2004 92, 265-274.

Chowdhury, Shakhawat. 2012. Heterotrophic bacteria in water distribution system: a review. Environ. Monit. Assess. 184, 6087-6137. DOI 10.1007/s10661-011-2407-x

Collins, S., D. Stevenson, J. Walker, and A. Bennett. 2017. Evaluation of Legionella real-time PCR against traditional culture for routine and public health testing of water samples. Journal of Applied Microbiology 122:1692-1703. DOI 10.1111/jam.13461

Committee on Public Water Supply Distribution Systems. 2006. Drinking Water Distribution Systems: Assessing and Reducing Risks. National Academies Press, Washington, DC. http:/www.nap.edu/catalog/11728.html

Duda, Scott, Julianne L. Baron, Marilyn M. Wagner, Radislav D. Vidic, and Janet E. Stout. 2015. Lack of correlation between Legionella colonization and microbial population quantification using heterotrophic plate count and adenosine triphosphate bioluminescence measurement. Environ. Monit. Assess. 187:393. DOI 10.1007/s10661-015-4612-5.

Department of Energy (DOE). 2016. Geothermal Heat Pumps; https://energy.gov/energysaver/geothermal-heat-pumps.

Grattard, Florence, Christophe Ginevra, Serge Riffard, Alain Ros, Sophie Jarraud, Jerome Etienne, and Bruno Pozzetto. 2006. Analysis of the genetic diversity of Legionella by sequencing the 23S-5S ribosomal intergenic spacer region: from phylogeny to direct identification of isolates at the species level from clinical specimens. Microbes and Infection 8: 73-83. DOI: 10.1016/j.micinf.2005.05.022

Green, Barry G. 1993. Heat as a Factor in the Perception of Taste, Smell, and Oral Sensation. pp. 173-185 in: Nutritional Needs in Hot Environments: Applications for Military Personnel in Field Operations, Bernadette M. Marriott, ed. Washington, DC: National Academy Press. http://www.nap.edu/catalog/2094.html

Jjemba, Patrick K. 2018. Additional Evaluation of the Impacts of Heat Exchanger Operation on Distribution Water Quality. American Water Research Laboratory, Delran, NJ. February 13, 2018.

LeChevallier, Mark W. 1999. Biofilms in Drinking Water Systems: Significance and Control. Chapter 10. In Identifying Drinking Water Contaminants. National Academy Press, Washington, DC. https://www.nap.edu/read/9595/chapter/12.

LeChevallier, Mark W., Orren D. Schneider, Lauren A. Weinrich, Patrick K. Jjemba, Patrick J. Evans, Jennifer L. Hooper, and Rick W. Chappell. 2015. An Operational Definition of Biostability in Drinking Water. Water Research Foundation, Denver, CO. Downloaded from http://www.waterrf.org/PublicReportLibrary/4312b.pdf. 
Lombardo, Tom. 2015. Innovative Approach to Geothermal Heating and Cooling. Engineering.com. October 19, 2015. http://www.engineering.com/DesignerEdge/DesignerEdgeArticles/ArticleID/10830/InnovativeApproach-to-Geothermal-Heating-and-Cooling.aspx.

Morris, Kendra F., American Water. 2018. Email communication to Ellen D. Smith, ORNL, February 19, 2018.

New York American Water. 2016. 2015 Annual Water Quality Report, Lynnbrook Operations District.

New York American Water. undated. NYAWC Geothermal Project Laboratory Materials and Methods. Sent to ORNL via email by Patrick K. Jjemba, January 21, 2017.

New York State Department of Health, Drinking Water Regulations, Part 5, Subpart 5-1, Public Water Systems - Tables, revised November 2011. Accessed at https://www.health.ny.gov/regulations/nycrr/title_10/part 5/subpart_5-1_tables.htm

Whelton, Andrew J., and Andrea M. Dietrich. 2004. Relationship between intensity, concentration, and temperature for drinking water odorants. Water Research 38: 1604-1614.

Whiley, Harriet, and Michael Taylor. 2016. Legionella detection by culture and qPCR: Comparing apples and oranges. Critical Reviews in Microbiology, 42:1, 65-74. DOI:10.3109/1040841S.2014.885930

Yang, G., R. Benson, T. Pelish, E. Brown, J. M. Winchell, and B. Fields. 2010. Dual detection of Legionella pneumophila and Legionella species by real-time PCR targeting the 23S-5S rRNA gene spacer region. 2009. Clinical Microbiology and Infection 16: 255-261. DOI: 10.1111/j.14690691.2009.02766.x

Zellner, D. A., W. F. Stewart, P. Rozin, and J. M. Brown. 1988. Effect of temperature on expectations and liking for beverages. Physiology \& Behavior 44: 61-68. 

APPENDIX A. SUMMARY LIST OF ANALYTES REPORTED TO ORNL BY NYAW 

SUMMARY LIST OF ANALYTES REPORTED TO ORNL BY NYAW

\begin{tabular}{lc} 
& Water Analyses \\
\hline & Inorganic Analytes \\
Calcium & Chromium \\
Chloride & Copper \\
Fluoride & Lead \\
Iron & Mercury \\
Magnesium & Nickel \\
Manganese & Selenium \\
Sodium & Silver \\
Sulfate & Thallium \\
Zinc & Alkalinity, Total (as $\left.\mathrm{CaCO}_{3}\right)$ \\
Antimony & Hardness, Calcium $\left(\mathrm{as} \mathrm{CaCO}_{3}\right)$ \\
Arsenic & Total Hardness (as $\left.\mathrm{CaCO}_{3}\right)$ \\
Barium & Total Dissolved Solids \\
Beryllium & Ammonia (as N) \\
Cadmium & Nitrate (as N) \\
\hline
\end{tabular}

\section{Purgeable Volatile Organics}

1,1,1,2-Tetrachloroethane 1,1,1-Trichloroethane 1,1,2,2-Tetrachloroethane $1,1,2$-Trichloroethane 1,1-Dichloroethane 1,1-Dichloroethene 1,1-Dichloropropene 1,2,3-Trichlorobenzene 1,2,3-Trichloropropane 1,2,4-Trichlorobenzene 1,2,4-Trimethylbenzene 1,2-Dichlorobenzene 1,2-Dichloroethane 1,2-Dichloropropane 1,3,5-Trimethylbenzene 1,3-Dichlorobenzene 1,3-Dichloropropane 1,4-Dichlorobenzene 2,2-Dichloropropane 2/4-Chlorotoluene 4-Isopropyltoluene Benzene Bromobenzene Bromochloromethane Bromodichloromethane Bromoform Bromomethane Carbon tetrachloride Chlorobenzene
Chloroethane

Chloroform

Chloromethane

cis-1,2-Dichloroethene

cis-1,3-Dichloropropene

Dibromochloromethane

Dibromomethane

Dichlorodifluoromethane

Ethylbenzene

Hexachlorobutadiene

Isopropylbenzene

$\mathrm{m}, \mathrm{p}$-Xylene

Methyl tert-butyl ether

Methylene chloride

n-Butylbenzene

n-Propylbenzene

o-Xylene

sec-Butylbenzene

Styrene

tert-Butylbenzene

Tetrachloroethene

Toluene

Total Trihalomethanes (calculated as sum of individual trihalomethanes)

trans-1,2-Dichloroethene

trans-1,3-Dichloropropene

Trichloroethene

Trichlorofluoromethane

Vinyl chloride 


\section{Other Water Analysis Parameters}

Free Chlorine Residual (field)

Color

Free Cyanide

Odor at $60^{\circ} \mathrm{C}$

Temperature (field)

Methylene Blue Active Substances (MBAS)

$\mathrm{pH}$ (field)

E. coli

Turbidity

Total coliform

Langelier saturation index (LSI; calculated

Heterotrophic Plate Count from other parameters)

\section{Corrosion Coupon Analyses}

Corrosion Rate

Pit Index

Legionella culture and qPCR data
ATP Accumulation Rate

Heterotrophic Plate Count (CFU/mm²) 
APPENDIX B. METHODOLOGY DESCRIPTIONS PROVIDED TO ORNL BY NYAW 



\section{NYAWC Geothermal Project Laboratory Materials and Methods}

\section{Metal coupon system setup}

Mild steel coupons (P/N CO100375104100, dimensions of 3" x 1/2" x 1/16"; 1-Hole Strip) were purchased from Alabama Specialty Products, Inc., Munford, AL. inserting metal coupons at the entrance and terminal of the heating/cooling system. For duplication, two coupons (A and B) were inserted into the flow stream using a retractable holder (ASPI, 2015; Figure 1). A similar setup was established at the heat exchanger effluent side. The retractable holder enabled aseptically removing the coupon from the pressurized pipe without shutting down the flow. Each coupon was be left in place for one month and exposed to a continuous flow to develop a biofilm. A new coupon was replaced each month as to compare relative growth rates throughout the year. Thus, a total 48 coupons (i. e., 2 locations/month $\times 2$ duplicates $\times 12$ months of sampling) were analyzed. At the appropriate time, each coupon was removed and placed in a sterile $50-\mathrm{mL}$ centrifuge tube and the tube filled with indigenous water to avoid biofilm shearing or drying in transit. The tubes

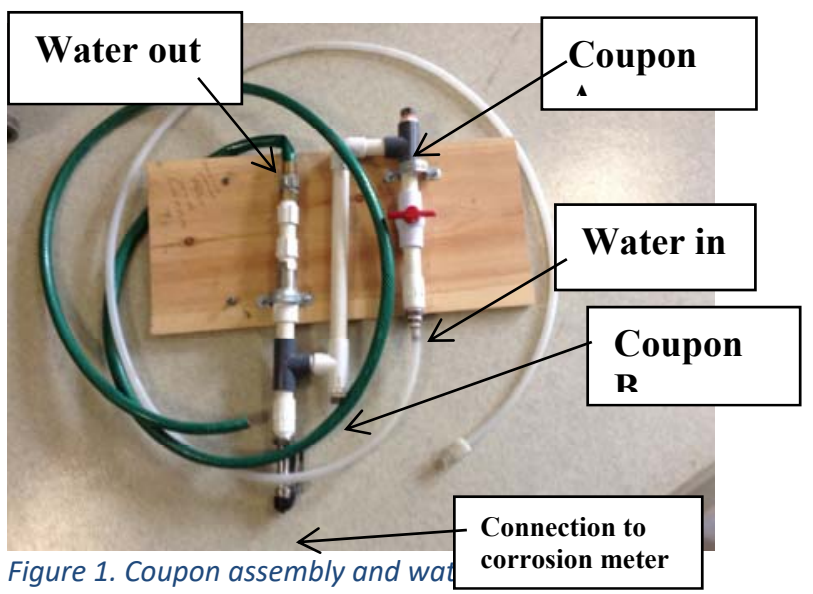
were shipped overnight on ice $\left(4{ }^{\circ} \mathrm{C}\right.$ to 8 ${ }^{\circ} \mathrm{C}$ ) the American Water laboratory in Delran for analysis.

\section{Biofilm recovery and analysis}

In the laboratory, the residual water was decanted from the tube and the coupon will be submerged in

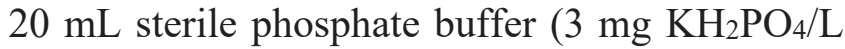
and $7 \mathrm{mg} \mathrm{K} 2 \mathrm{HPO}_{4} / \mathrm{L} ; \mathrm{pH} 7$ ). The biofilm was carefully scrapped off the metal coupon with a sterile brush and each tube filled with phosphate buffer up to the 30-mL mark (Figure 2) to provide a uniform biofilm suspension. ATP assay uses a single reagent (BacTiter-Glo ${ }^{\mathrm{TM}}$ Reagent) added to a biofilm suspension and measuring the luminescence. The BacTiter-Glo ${ }^{\mathrm{TM}}$ Reagent relies on the properties of a proprietary thermostable luciferase enzyme isolated from fireflies. The

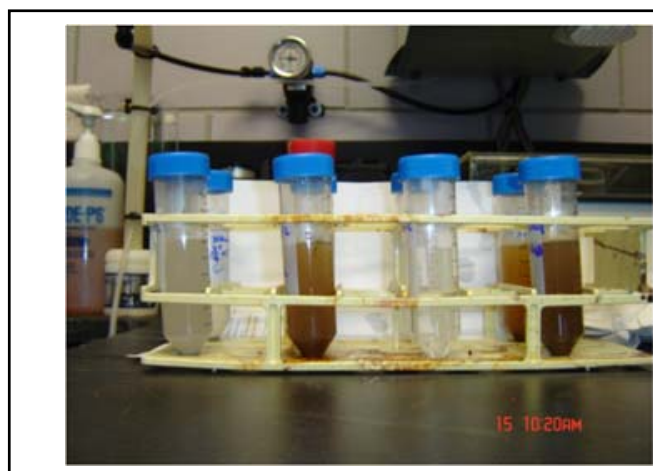

Figure 2. Typical coupon-derived biofilm suspension used for ATP determination. enzyme requires energy from ATP to produce light and the kit also has a proprietary formulation for extracting ATP from microorganisms. Triplicate aliquots of $100 \mu \mathrm{L}$ biofilm 
suspension was added to an equal volume of BacTiter-Glo ${ }^{\text {TM }}$ Reagent (Promega, Madison, WI). The mixture was incubated at $30{ }^{\circ} \mathrm{C}$ for $1.5 \mathrm{~min}$ with periodic mixing every 30 seconds. Luminescence (relative light units) was measured exactly $30 \mathrm{~s}$ using the GloMax $^{\text {TM }}$ 20/20 luminometer (Promega, Madison, WI). The luminescence value was converted to ATP concentrations based on a calibration curve obtained by spiking serial dilutions of a $10 \mathrm{mM}$ ATP stock incubated with the biofilm suspension which had been inactivated by heating at $60^{\circ} \mathrm{C}(21$ hours) and then treated as any other sample (Veltens et al., 2007; LeChevallier et al., 2015). A typical calibration curve is shown in Figure 3. ATP results were ultimately expressed on a $\mathrm{pg} A T P / \mathrm{cm}^{2}$ basis as summarized in a sample set of raw data in Table 1.

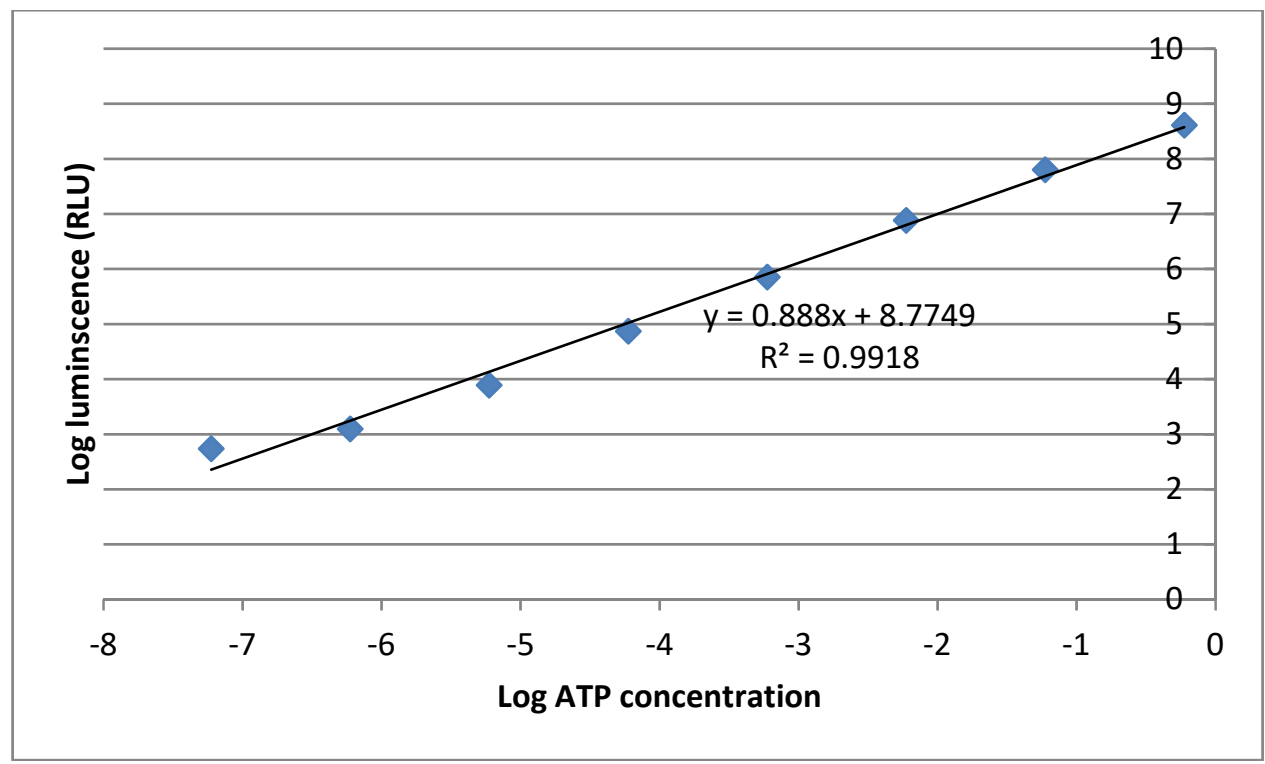

Figure 3. A typical standard calibration curve with an ATP stock serial diluted by spiking in deactivated a biofilm suspension.

An aliquot the biofilm suspension was used to determine heterotrophic bacteria in the biofilm using the spread-plate method (Standard Method 9215C [Eaton et al., 2005]) on R2A agar. The plates were incubated at $22 \pm 1^{\circ} \mathrm{C}$ for one week. Heterotrophic bacteria (typically referred to as HPCs) are used frequently in the water industry to provide information about the microbiological and aesthetic quality of drinking water. The results were expressed on a per unit area (i.e., $\mathrm{HPC} / \mathrm{mm}^{2}$ ) of the coupon. 
Table 1. Sample spreadsheet entry used to calculate the ATP accumulation rate in the coupon biofilm

\begin{tabular}{|c|c|c|c|c|c|c|c|c|c|c|c|c|}
\hline $\begin{array}{l}\text { Coupon } \\
\text { ID } \\
\end{array}$ & Rep & $\begin{array}{l}\text { Luminescence } \\
\text { (RLUs) }\end{array}$ & $\begin{array}{l}\text { Log } \\
\text { luminescence }\end{array}$ & $\begin{array}{l}\text { Log ATP } \\
\text { (ug/100uL) }\end{array}$ & ATP (ug/100uL) & $\begin{array}{l}\text { ATP } \\
\text { (ug/30mL) }\end{array}$ & $\begin{array}{l}\text { ATP } \\
\left(\mathrm{ug} / \mathrm{mm}^{2}\right)\end{array}$ & $\begin{array}{l}\text { ATP } \\
\left(\mathrm{pg} / \mathrm{mm}^{2}\right)\end{array}$ & $\begin{array}{l}\text { Installation } \\
\text { date }\end{array}$ & $\begin{array}{l}\text { Harvest } \\
\text { date }\end{array}$ & $\begin{array}{l}\text { Days } \\
\text { in DS }\end{array}$ & $\begin{array}{l}\text { Accumulation ate } \\
\text { (pgATP/mm2/day) }\end{array}$ \\
\hline \multirow{5}{*}{$\begin{array}{l}\text { INF-A- } \\
04202016\end{array}$} & 1 & 5389 & 3.731508184 & -5.679495289 & 2.09173E-06 & 0.000627518 & $4.27464 \mathrm{E}-07$ & 0.427464359 & $3 / 16 / 2016$ & $4 / 20 / 2016$ & 35 & 0.012213267 \\
\hline & 2 & 5046 & 3.702947246 & -5.711658507 & $1.94241 \mathrm{E}-06$ & 0.000582724 & $3.96951 \mathrm{E}-07$ & 0.39695081 & $3 / 16 / 2016$ & $4 / 20 / 2016$ & 35 & 0.011341452 \\
\hline & 3 & 5277 & 3.722387094 & -5.689766786 & $2.04283 \mathrm{E}-06$ & 0.00061285 & 4.17473E- 07 & 0.41747302 & $3 / 16 / 2016$ & $4 / 20 / 2016$ & 35 & 0.011927801 \\
\hline & Mean & 5237.333333 & & & $2.02566 \mathrm{E}-06$ & & 4.13963E-07 & 0.41396273 & & & & 0.011827507 \\
\hline & SD & 174.9066418 & & & $7.61241 \mathrm{E}-08$ & & $1.55567 \mathrm{E}-08$ & 0.015556695 & & & & 0.000444477 \\
\hline
\end{tabular}


Duplicate $100 \mu \mathrm{L}$ aliquots of the biofilm suspension were plated on BCYE agar supplemented with GVPC (Oxoid) and a Legionella agar enrichment (BD Difco, Sparks, MD). To ensure detection of low levels of Legionella, another aliquot of $20 \mathrm{~mL}$ biofilm suspension was filtered through a $0.2 \mu \mathrm{m} 47-\mathrm{mm}$ diameter polycarbonate filter. The filter was aseptically removed and inserted into a tube containing $5 \mathrm{~mL}$ sterile water. The tube was vortexed at high speed to re-suspend the bacteria. To eliminate non-Legionella organisms during this selection growth process, $1 \mathrm{~mL}$ of the sample was pretreated with acidified potassium chloride $(0.2 \mathrm{M} \mathrm{KCl} / \mathrm{HCl} ; \mathrm{pH}=2.2)$ for 15 minutes at room temperature and thereafter $0.1 \mathrm{~mL}$ spread-plated on BCYE agar supplemented with GVPC (Oxoid) and a Legionella agar enrichment (BD Difco, Sparks, MD). Thereafter, an aliquot of $0.1 \mathrm{~mL}$ was streaked on BCYE agar supplemented with GVPC (Oxoid) and a Legionella agar enrichment (BD Difco, Sparks, MD). This extra step is recommended under CDC guidelines for detecting low levels of Legionella in environmental samples. The plates were incubated at $36.5^{\circ} \mathrm{C}$ with $2.5 \% \mathrm{CO}_{2}$ and $94 \%$ relative humidity. Growth on the plates was monitored for up to 10 days. Though any growth was ever detected, where it occurred, the presumptive Legionella sp. colonies were streaked on BCYE without any cysteine. Most species require iron salts and cysteine for growth (Eaton et al., 2005; Lück et al., 2004). Failure to grow in the absence of cysteine confirmed the streaked parent colonies as Legionella sp. (NHS, 2007).

\section{References}

ASPI (2015) Length calculation and accessories for retractable probes and coupon holders (URL: http://www.alspi.com/length.pdf; accessed 2/13/2015)

Eaton, A. D., Clesceri, L.S., Rice, E.W., Greenberg, A.E., Eds. Standard Methods for the Examination of Water and Wastewater, 21st ed.; American Public Health Association: Washington, DC, 2005.

LeChevallier M.W., O.D. Schneider, L.A. Weinrich, P.K. Jjemba, P.J. Evans, J.L. Hooper, and R.W. Chappell (2015b) An Operational Definition of Biostability in Drinking Water. Water Research Foundation Report\# 4312b, Denver, Colorado. (http://www.waterrf.org/PublicReportLibrary/4312b.pdf).

Lück, P. C.; Igel, L.; Helbig, J. H.; Kuhlisch, E.; Jatzwauk, L. Comparison of commercially available media for the recovery of Legionella species. Int. J. Hyg. Environ. Health 2004, 207, 589-593.

NHS. Identification of Legionella Species. http://www.hpastandardmethods.org.uk/documents/bsopid/pdf/bsopid18.pdf (accessed Nov 2007), 2007. Promega (2009) Technical Bulletin - BacTiter-Glo ${ }^{\mathrm{TM}}$ Microbial Cell Viability Assay. Part TB337.

Velten S., F. Hammes, M. Boller, and T. Egli (2007) ATP measurement as a means for directly estimating active biomass. Promega Notes 97:15-17. 


\section{Additional Evaluation of the Impacts of Heat Exchanger Operation on Distribution Water Quality}

Patrick K. Jjemba PhD

American Water Research Laboratory, Delran NJ

February 13, 2018

\section{Summary}

This report describes the results of the second water quality test performed on municipal water running through a geothermal heat exchanger. The test's objective was to determine whether the heat exchanger would cause an increase in Legionella levels in the water passing through the system. American Water's Water Research and Development department used a culture-based method and a PCR method to identify any change in Legionella and based on the evidence collected to date, has concluded the heat exchanger does not appear to increase Legionella risk in the effluent water.

Using strict protocols for testing for the presence of Legionella on the influent and effluent coupons, we found zero culturable Legionella in any sample, but found DNA markers for Legionella that were confirmed as originating from Legionella in only $10 \%$ of the samples (six out of 60 total). Of the six samples, Legionella was detected in the influent in four different months and only once in the effluent in a separate month. The results demonstrated that within this testing period the heat exchange system did not result in an increase in Legionella, even with an observed average temperature increase of $2.9^{\circ} \mathrm{C}$.

Additional modeling work was completed to simulate the impact of returning the higher temperature effluent water to the drinking water distribution system. While several options were modeled under highly conservative conditions (i.e., assuming that temperature was conserved and only impacted by dilution, but not dissipating heat to the piping or surrounding earth), two scenarios were able to keep any impact to the local distribution system to less than $3{ }^{\circ} \mathrm{C}$ increase anywhere within the influence area.

\section{Background}

A geothermal heat pump system was installed on a potable water distribution main in 2015 to provide heating and cooling to a 40,000 square foot elementary school in New York. Water passed through the heat exchanger is currently running to waste pending a permit from the local Department of Health (DOH) to reinject it into the distribution main and "close the loop."

American Water performed water quality testing during the cooling season to understand the heat exchanger's impact to water quality as a result of transferring heat from the building to the municipal water. This timeframe was selected as the system is intensively used at that time (i.e., cooling season) which can increase water temperature resulting in Legionella growth. The first testing occurred during two consecutive cooling seasons and the second testing occurred during the following cooling season (Table 1). 
Table 1. Testing Phases and Dates

\begin{tabular}{cc}
\hline Testing Phase & Dates \\
\hline 1 & August 2015 -September 2016 \\
2 & May - October 2017 \\
\hline
\end{tabular}

Legionella detection during the first testing phases was solely based on a laboratory growth medium (i.e., BCYE agar) and showed presumptive Legionella in one out of 24 coupons (i.e., $4.2 \%$ ) tested. The presumptive Legionella were at a very low concentration of 1.2 colony forming units (cfu) per $4 \mathrm{~mm}^{2}$ of the coupon surface area. However, genotype confirmation of the presence of Legionella was not possible due to loss of the sample prior to re-analysis.

Out of an abundance of caution, monitoring was extended through the following spring and summer period (i.e., May to October 2017). The second testing phase mimicked the first testing phase's use of the conventional culture method and added a more sensitive molecular analysis technique (qPCR). In the second testing phase, we specifically wanted to determine whether the heat exchanger increases the risk of Legionella amplifying in the outflow line.

\section{Methodology and Modeling Information Provided in the Appendix}

\section{Results and Discussion}

Water $\mathrm{pH}$, chlorine residual and temperature during the testing period is summarized in Table 2 and are shown graphically in Figure 1 and 2. As expected, temperature increases across the heat exchange system while the chlorine residual was maintained, indicating stability of the disinfectant through the system. Water $\mathrm{pH}$ was mostly unchanged except in mid-July when $\mathrm{pH}$ drops (i.e., increase in acidity) of 0.2 to 1 unit were recorded. The $\mathrm{pH}$ drop was significantly different from maximum $\mathrm{pH}$ in the influent and effluent. However, these observed changes in $\mathrm{pH}$ are more likely due to sensor drift between the influent and effluent lines than any real change in $\mathrm{pH}$ due to the lack of chemical mechanism, which would explain such a shift.

Table 2: Summary of physicochemical water quality throughout testing phase 2

\begin{tabular}{|c|c|c|c|c|c|c|c|c|c|}
\hline \multirow{2}{*}{$\begin{array}{l}\text { Statistical } \\
\text { parameter }\end{array}$} & \multicolumn{3}{|c|}{ Water pH } & \multicolumn{3}{|c|}{ Chlorine residual $(\mathrm{mg} / \mathrm{L})$} & \multicolumn{3}{|c|}{ Water temperature $\left({ }^{\circ} \mathrm{C}\right)$} \\
\hline & Influent & Effluent & Difference & Influent & Effluent & Difference & Influent & Effluent & Difference \\
\hline Minimum & 5.33 & 5.16 & -0.17 & 0.3 & 0.3 & 0 & -0.25 & 1.96 & 2.21 \\
\hline Maximum & 7.24 & 7.17 & -0.07 & 1.11 & 1.14 & 0.03 & 16.86 & 19.62 & 2.76 \\
\hline Mean & 6.25 & 6.02 & -0.23 & 0.66 & 0.67 & 0.01 & 10.76 & 13.67 & 2.91 \\
\hline Standard deviation & 0.56 & 0.49 & & 0.27 & 0.28 & & 4.32 & 3.19 & \\
\hline $\operatorname{Lsd}(p<0.05)^{1}$ & 1.31 & & & 1.41 & $\mathrm{NS})^{2}$ & & & 31 & \\
\hline
\end{tabular}

${ }^{1}$ Lsd $=$ least significant difference at the $5 \%$ level of significance

${ }^{2} \mathrm{NS}=$ Not significantly different 


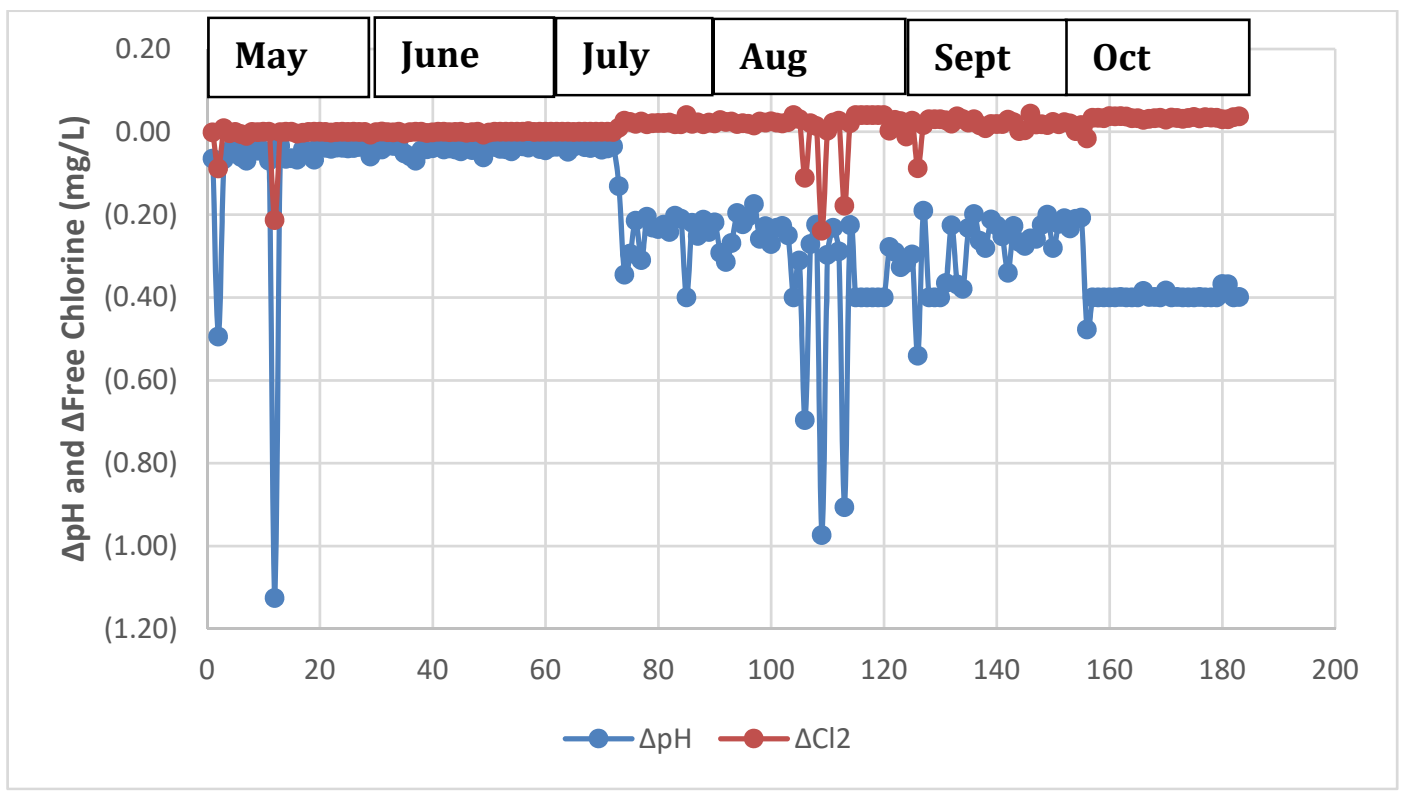

Figure 1. Difference $(\Delta)$ in (A) water $\mathrm{pH}$ and chlorine residual

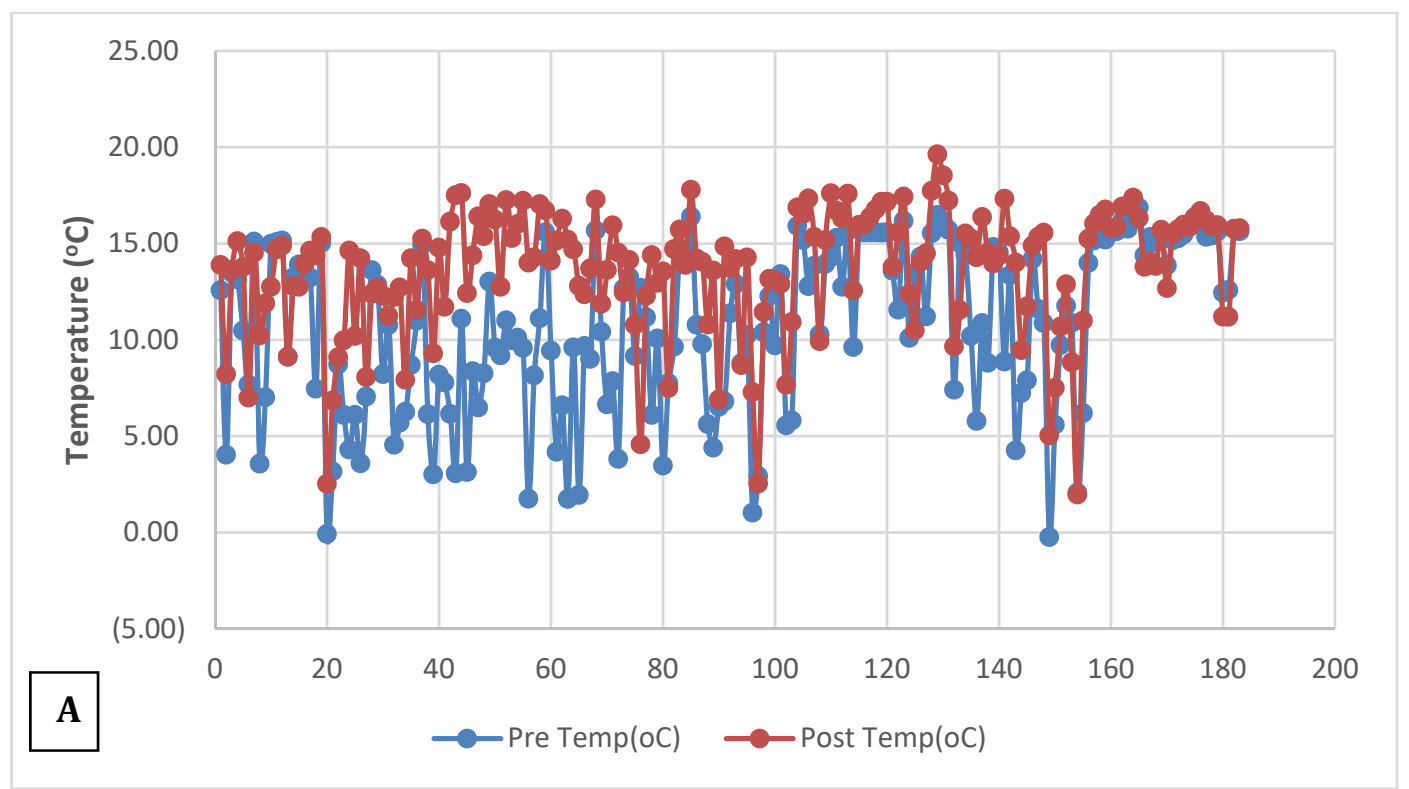




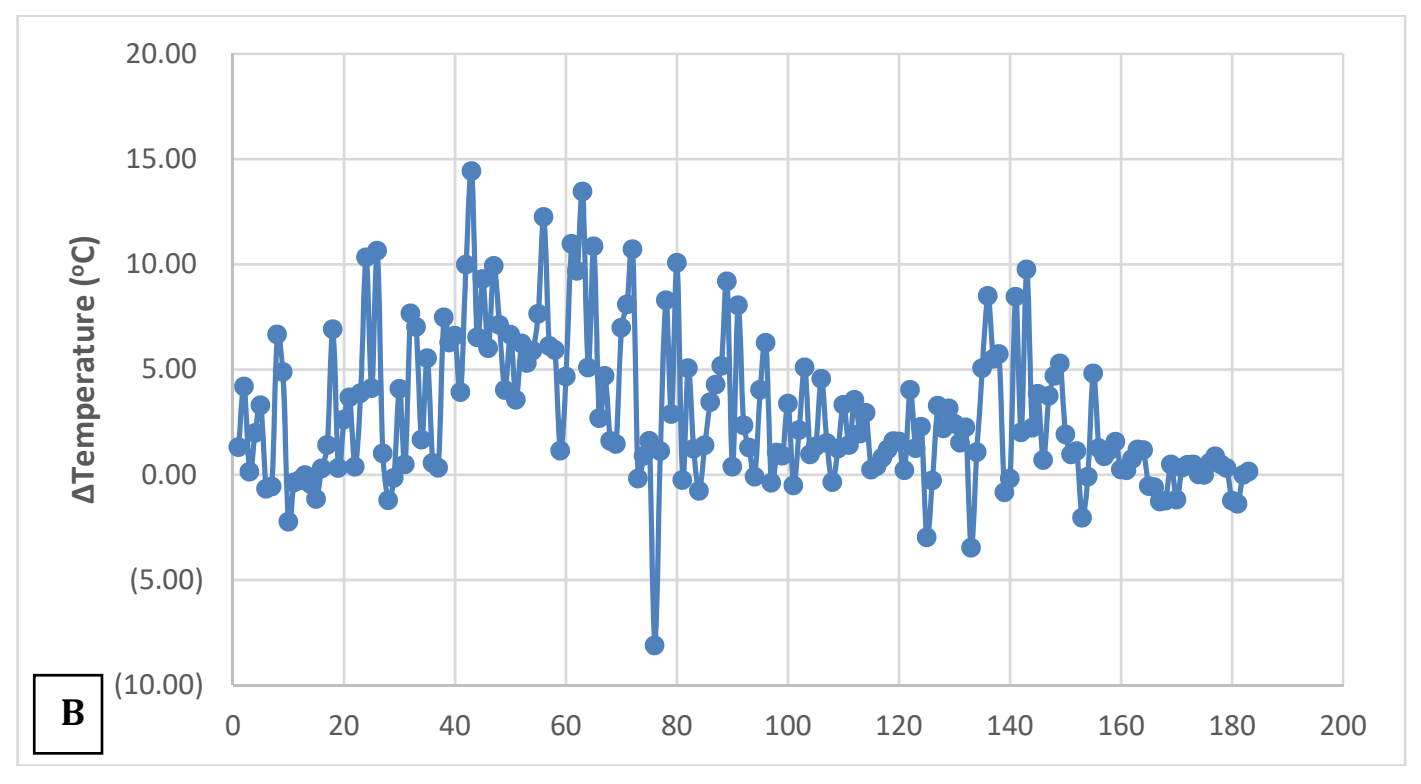

Figure 2. Temperature trends (A) in the pre- and post heat exchanger (B) corresponding differences $(\Delta)$ in the effluent compared to the influent

The ATP accumulation rate, indicating the level of microbial activity, was not different in the influent and effluent to the heat exchanger. Mean biofilm accumulation rates were $0.009 \mathrm{pg}$ $\mathrm{ATP} / \mathrm{mm}^{2} /$ day and $0.010 \mathrm{pg} \mathrm{ATP} / \mathrm{mm}^{2} /$ day in the influent and effluent loops respectively. The low biofilm accumulation rate is probably indicative of the stable groundwater used in this study. By comparison, a survey of 26 U.S. drinking water supply systems had mean ATP accumulations rates seven times as high (i.e., $0.074 \mathrm{pg} \mathrm{ATP} / \mathrm{mm}^{2} /$ day; LeChevallier et al., 2015).

Heterotrophic bacteria (HPC) concentrations varied from month to month. We calculated the geometric mean to "normalize" the heterotrophic bacteria densities and found that the mean influent and effluent HPCs were not statistically different after factoring in the standard deviation. Thus, the biofilm did not significantly change as water flowed through the heat exchanger indicating the geothermal system did not negatively impact water quality. Likewise, the relationship between ATP and HPC were identical in pre- and post-exchanger as show in Figure 3. The lack of change in relationship between ATP and HPC indicates that there was no change in the water quality that would favor bacterial regrowth in the water.

Table 3 provides an overview of the various water quality parameters that were measured to analyze the heat exchanger's impact on water quality on the days the coupons were retrieved. 
Table 3: Geothermal unit influent and effluent attributes on days the coupons were retrieved

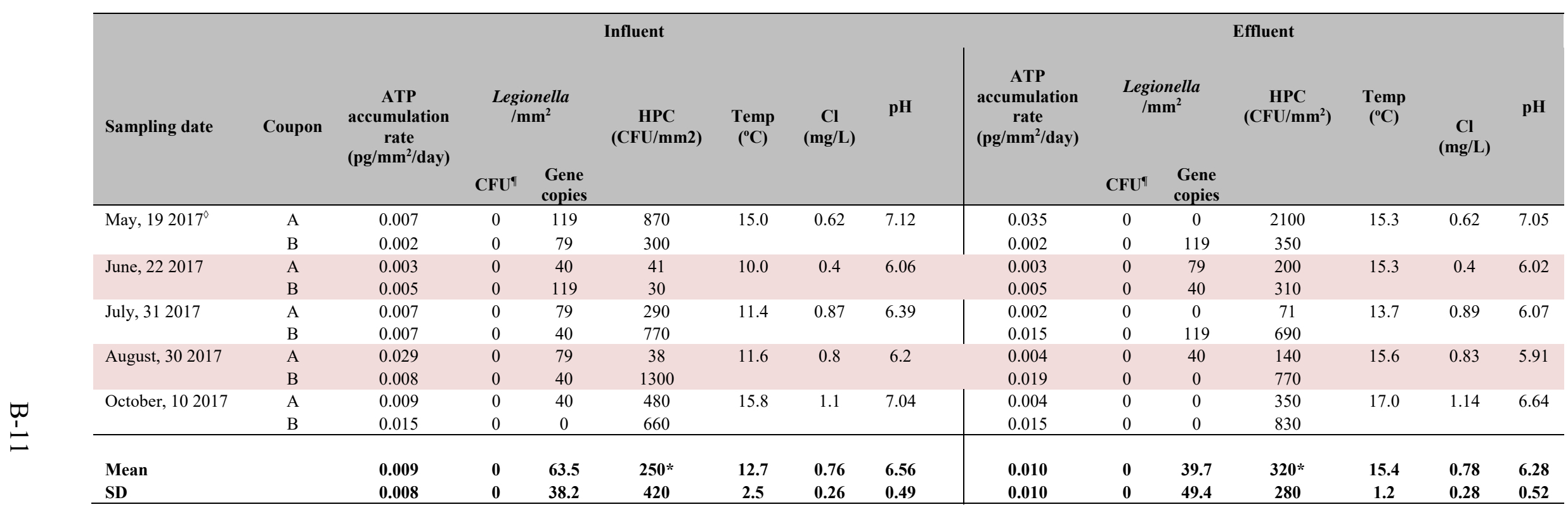

"CFU=Colony forming units (i.e., number of microbial colonies formed on laboratory growth media in culture testing method as an indicator of Legionella colony abundance)

-The coupons harvested in May were in place for 8 months as compared to all of the others which were in place for about one month

*Geometric mean 

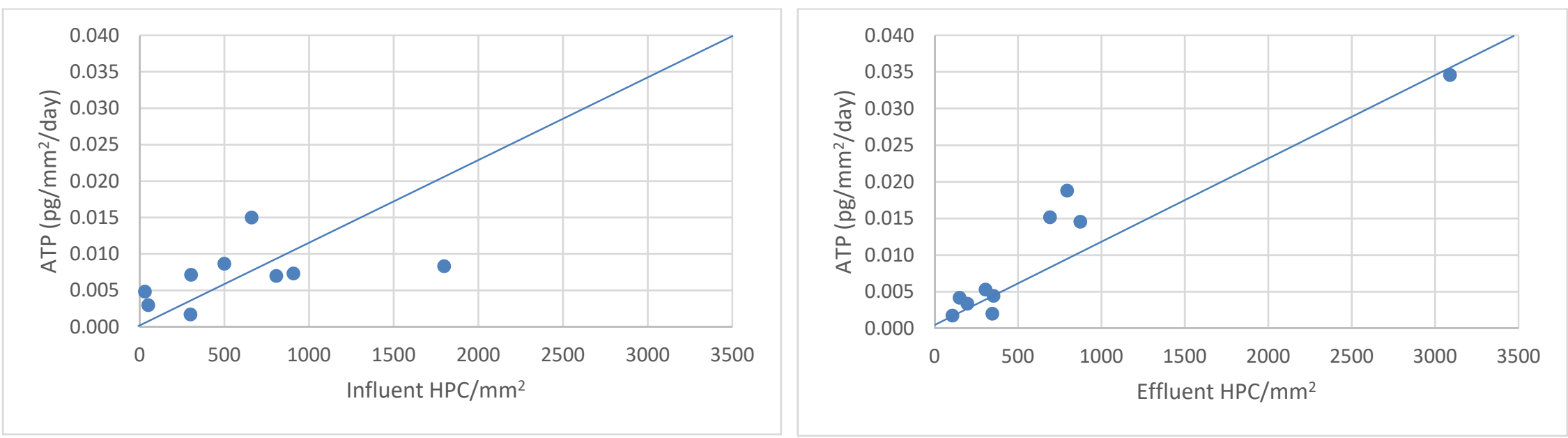

Figure 3. Relationship between HPC and ATP in pre- and post-heat exchanger biofilms showing same-slope lines to demonstrate central tendency of data. 


\section{PCR and DNA Sequencing}

While the culture method did not detect Legionella, five influent and one effluent samples out of 60 were positive for Legionella using the qPCR molecular method and sequencing (Figure 4). The PCR test assigns each sample a positive, uncertain or negative indicator expressed through red, blue and green dots. A positive indicator (red dot) means the PCR instrument identified an organism with certain predefined DNA targets. An uncertain indicator (blue dot) means the PCR instrument is uncertain if the organism matches the predefined DNA targets. In the initial PCR run, as seen in rows A - E in Figure 3, there were 10 positive and uncertain PCR wells for the effluent samples compared to 16 positive and uncertain wells in the influent.

In order to determine if the PCR results were in fact Legionella and to identify the species of Legionella, additional DNA sequencing was conducted on the positive and uncertain samples. On sequencing, only three of PCR products were confirmed as Legionella. Three additional results were weakly shown to be Legionella but were still counted as positive samples out of an abundance of caution (Table 4).

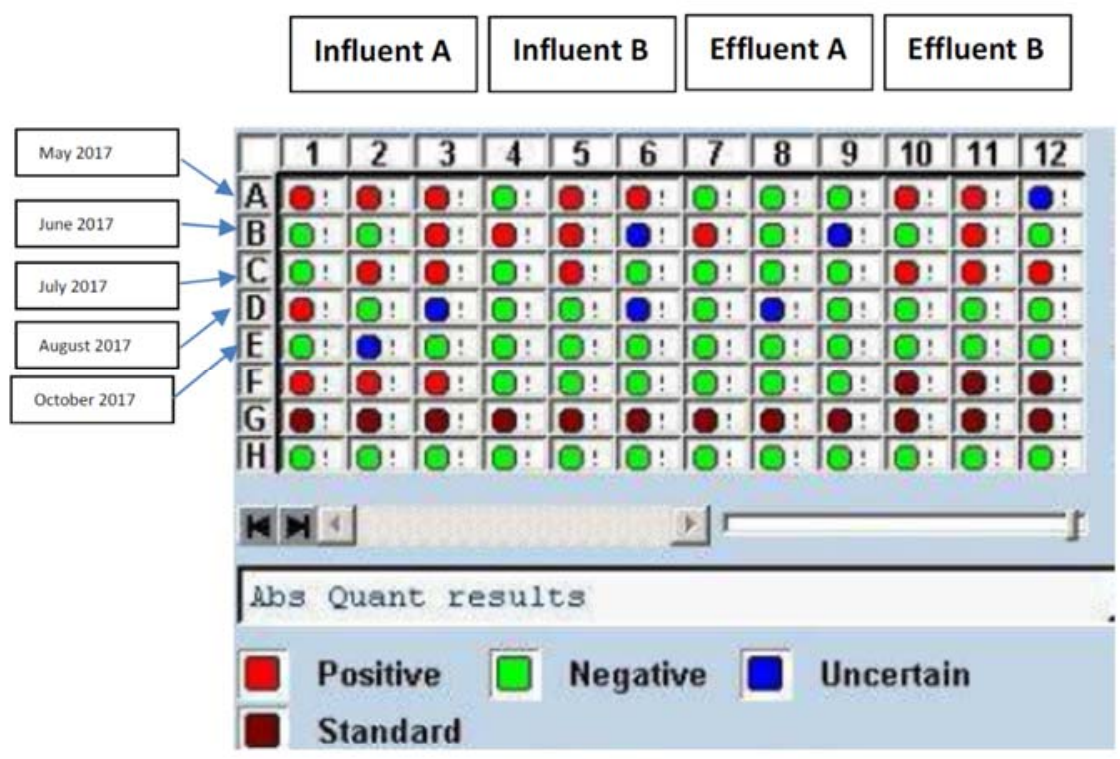

Figure 4. DNA amplification with primers specific for Legionella. DNA in F1, F2 and F3 was from a positive control.

Table 4. DNA Sequencing Confirmation of Legionella Species

\begin{tabular}{|c|c|c|c|}
\hline Date & Coupon & $\begin{array}{l}\text { PCR plate } \\
\text { location }\end{array}$ & Sequencing Results \\
\hline May $19^{\text {th }}, 2017$ & Influent $\mathrm{A}$ & $\mathrm{A} 2$ & Legionella sp. \\
\hline June 22 $2^{\text {nd }}, 2017$ & Effluent B & B11 & Legionella sp. \\
\hline \multirow{3}{*}{$\begin{array}{l}\text { July } 31^{\text {st }}, 2017 \\
\text { August } 30^{\text {th }}, 2017\end{array}$} & Influent B & $\mathrm{C} 5$ & Legionella sp. \\
\hline & Influent $\mathrm{A}$ & D3 & Legionella sp. \\
\hline & Influent B & D6 & Legionella sp. \\
\hline October $10^{\text {th }}, 2017$ & Influent $\mathrm{A}$ & $\mathrm{F} 2$ & Legionella pneumophila \\
\hline
\end{tabular}




\section{Modeling Results of Increased Temperature in Distribution}

Several modeling scenarios were evaluated to determine the magnitude of impact from the recirculation of the heat exchange effluent back to the drinking water distribution system. It is important to note that in the model simulations, temperature was treated like a conservative dissolved constituent that would simply respond to dilution effects; i.e., the temperature would increase proportionally if blended with a warmer water, and then would remain unchanged until it reached a colder water. However, in reality temperature is not conservative and the temperature of the water in the pipes will shift toward equilibrium with the surrounding pipe and ground material. Thus, the temperature results that were modeled are highly conservative and do not take into account any cooling that would naturally occur in distribution. Thus, results indicated that when a significant portion of heat exchange effluent were re-circulated through the local distribution system and back to the influent, temperature increase could build up more than a single-pass temperature increase, and might result in water quality deterioration associated with higher temperatures.

Additional model scenarios were therefore tested and showed that the re-circulation temperature effects could be readily minimized or eliminated by increasing flow through the impact area. Figure 5 shows modeled results of the temperature increase when a nearby well located approximately 0.4 miles north is turned on (Well 10 Lynbrook-Hawthorne Ave, pumping about 1.7MGD). With most of the water for the school originating from Well 10, the model estimated minimal short-circuiting, and the first downstream customer having a temperature increase of less than $3^{\circ} \mathrm{C}$, i.e., the temperature increase after a single pass of the heat exchanger. The daily difference in influent and effluent temperature (Figure $2 \mathrm{~B}$ ) was at $3^{\circ} \mathrm{C}$ or greater in $41.5 \%$ instances over 183 days of monitoring.

The actual system design minimizes the risk of warmer effluent water recirculating back to the heat exchange system. Once the water is returned to the distribution system, it will be pushed to the streets to the north of the school and would have to travel through one mile of pipe, which is four feet below the ground, before it could reach the intake of the heat exchanger again. We assume the temperature of the water will return to ambient ground water temperature as it travels back through the pipe.

The system has controls in place to maintain no more than a 2.78 degree Celsius (five degree Fahrenheit) change in temperature between the influent and effluent. Once the effluent is discharged to the distribution main, the SCADA system will automatically monitor the temperature change between the influent and effluent and control the pumps to increase or decrease the water flow through the heat exchanger to maintain the desired delta T. For example, on a particularly hot day, the pumps will speed up to increase the amount of water flowing through the heat exchanger to minimize the increased temperature of effluent. Under the pilot phase where water is discharged to an aquifer instead of the distribution system, the rate of flow through the heat exchanger is fixed and adjusted manually. The pumps generally run at 220 gallons per minute (gpm) have the ability to increase the flow rate up to 350 gpm. 


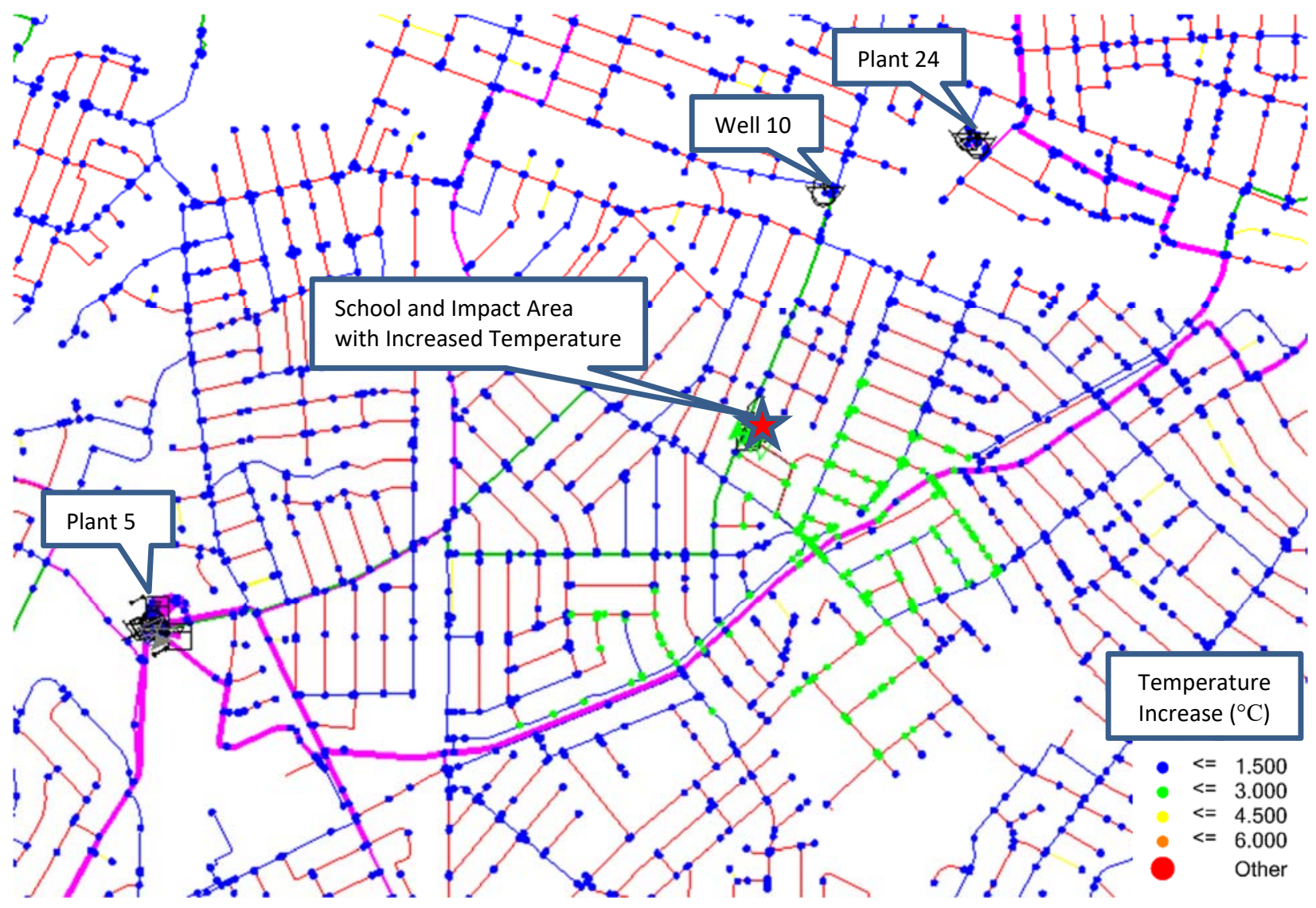

Figure 5. Modeled temperature impact of introducing heat exchange effluent to distribution with Well 10 online-color coded maximum temperature increase in the impact area

\section{Summary and Conclusions}

Under the single pass testing, the heat exchanger increased temperatures by an average of $2.9^{\circ} \mathrm{C}$, but the disinfectant residual was maintained. Biofilm formation and related microbial activity was monitored with ATP as well as heterotrophic bacteria growth and did not significantly change in the post heat exchanger water. Legionella was not detected using the culture method widely used by the industry as the gold standard. The more sensitive molecular method rarely detected Legionella in the water. Even then, the detected pieces of Legionella DNA were in very low concentrations as reflected by the low gene copy number. Only one influent sample at the testing site had L. pneumophila. When present, Legionella was not amplified in the heat exchanger.

Hydraulic modeling evaluated the heat exchanger impact on temperature increase after re-introducing its effluent into the distribution system. Under average/maximum day demand conditions, temperature increase at the first downstream customer had potential to build up more than the single-pass temperature increase due to re-circulation, which might cause deterioration of water quality. However, with operational adjustment (turning on Well 10) or capital improvement (re-introducing the effluent to a nearby 24-inch transmission), re-circulation could be readily minimized or eliminated. Nowhere within the distribution would system temperature increase more than $3{ }^{\circ} \mathrm{C}$. In conclusion, based on the evidence collected to date the heat exchanger does not appear to increase the risk of Legionella amplifying in the outflow line or impact distribution system temperatures once the water is re-introduced into the distribution system. 


\section{References}

Grattard F, Ginevra C, Riffard S, Ros S, Jarraud S. 2006. Analysis of the genetic diversity of Legionella by sequencing the $23 \mathrm{~S}-5 \mathrm{~S}$ rRNA region- from phylogeny to direct identification of isolates at the species level from clinical specimens. Microbes and Infection 8:73-83.

LeChevallier M.W., O.D. Schneider, L.A. Weinrich, P.K. Jjemba, P.J. Evans, J.L. Hooper, and R.W. Chappell (2015) An Operational Definition of Biostability in Drinking Water. Water Research Foundation Report\# 4312b, Denver, Colorado. (http://www.waterrf.org/PublicReportLibrary/4312b.pdf).

Promega (2009) Technical Bulletin - BacTiter-Glo ${ }^{\mathrm{TM}}$ Microbial Cell Viability Assay. Part TB337.

Velten S., F. Hammes, M. Boller, and T. Egli (2007) ATP measurement as a means for directly estimating active biomass. Promega Notes 97:15-17.

Grattard 


\section{Appendix}

\section{Methodology}

Pipe loops installed in July 2015 on the inlet and outlet side of the heat exchanger have ports where two coupons (i.e., A and B) are inserted and retrieved as needed (Figure A-1). Results from the first phase were summarized by ORNL in a previous report and are not covered in this report. There was a period of eight months from when the first phase ended and when the second phase began. The coupons were left in place (with the water flowing) from the end of the first phase to the beginning of the second testing phase. This provided an opportunity to harvest biofilms developed over eight months as compared to the typical 30-day duration. Additional monthly coupon harvestings were conducted in June, July, August and October 2017 and shipped to the laboratory overnight on ice. Residual chlorine disinfect, $\mathrm{pH}$ and water temperature were collected using an online monitor once every hour.

In the laboratory, the biofilm was scrapped off each coupon and suspended in $30 \mathrm{~mL}$ phosphate buffer (Figure A-2). Aliquots were used to determine microbial activity (using adenosine triphosphate-ATP as a surrogate), heterotrophic bacteria (HPC), and Legionella (Figure A-3). Adenosine triphosphate (ATP) measurements depended on BacTiter-Glo ${ }^{\mathrm{TM}}$ Reagent with a proprietary thermostable luciferase enzyme isolated from fireflies. The enzyme requires energy from ATP to produce light detected by luminescence (Veltens et al., 2007; Promega, 2009). It was determined in triplicate aliquots of $100 \mu \mathrm{L}$ biofilm suspension by adding to an equal volume of BacTiter-Glo ${ }^{\mathrm{TM}}$ Reagent (Promega, Madison, WI). The mixture was incubated at $30{ }^{\circ} \mathrm{C}$ for 1.5 min with periodic mixing every 30 seconds. Luminescence (relative light units) was measured exactly 30 s using the GloMax ${ }^{\mathrm{TM}}$ 20/20 Luminometer (Promega, Madison, WI). The luminescence value was converted to ATP concentrations based on a calibration curve obtained by spiking serial dilutions of a $10 \mathrm{mM}$ ATP stock incubated with the biofilm suspension which had been inactivated by heating at $60^{\circ} \mathrm{C}(21$ hours) and then treated as any other sample (Veltens et al., 2007; LeChevallier et al., 2015). The final ATP concentration was related to the surface area of the coupon and formation rate per day determined based on the number of days each coupon had been in place. Heterotrophic bacteria in the biofilm were determined in duplicates using the culture spread-plate method (Standard Method 9215C [Eaton et al., 2005]) on R2A agar. To break up clumps, the sample was vortexed at maximum speed for $30 \mathrm{~s}$ and tenfold dilutions plated. The plates were incubated at $22 \pm 1^{\circ} \mathrm{C}$ for one week. HPCs were expressed on a per unit area (i.e., $\mathrm{HPC} / \mathrm{mm}^{2}$ ) of the coupon. 


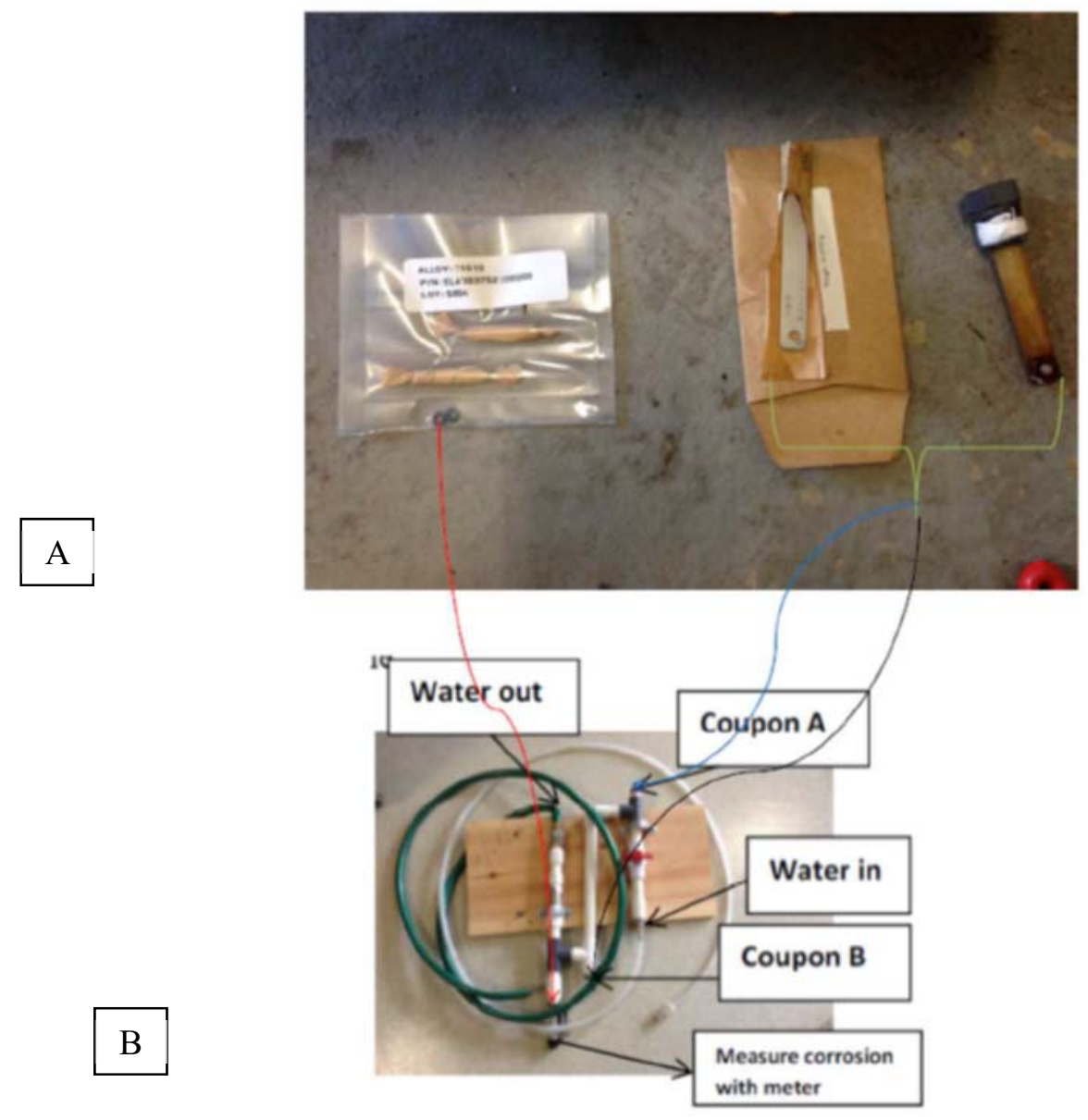

Figure A-1. Coupons (A) and coupon assembly in the pipeloop (B) in relation to water flow

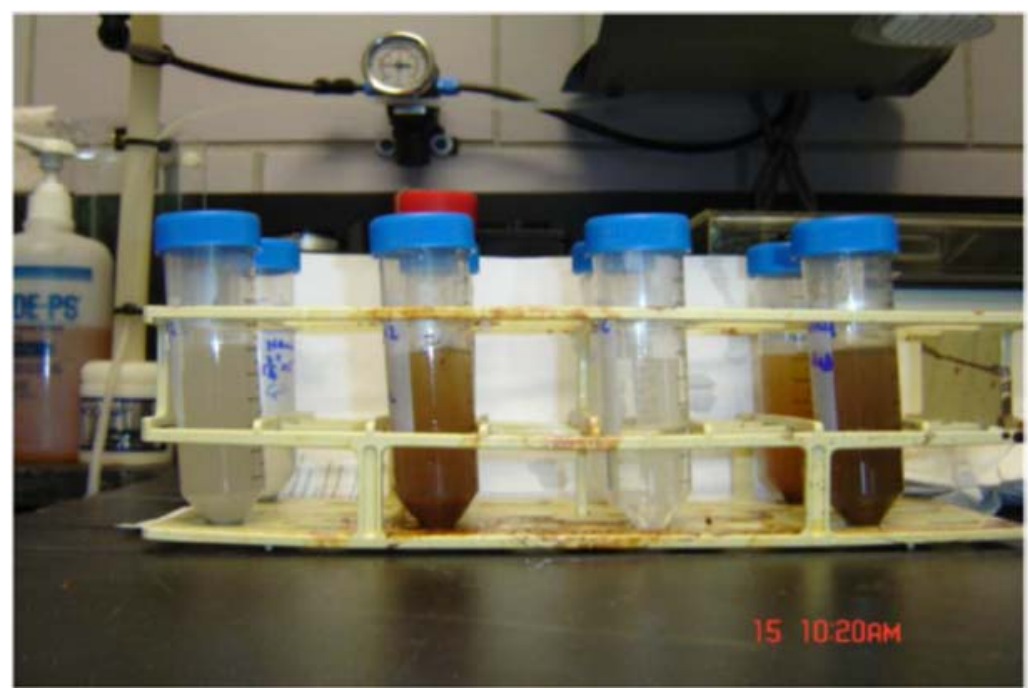

Figure A-2. Harvested biofilm suspension 
Duplicate $100 \mu \mathrm{L}$ aliquots of the biofilm suspension were plated on BCYE agar supplemented with GVPA (Oxoid) and a Legionella agar enrichment (BD Difco, Sparks, MD; Figure A-3). To ensure detection of low levels of Legionella, another aliquot of $20 \mathrm{~mL}$ biofilm suspension was filtered through a $0.2 \mu \mathrm{m} 47-\mathrm{mm}$ diameter polycarbonate filter. The filter was aseptically removed and inserted into $10 \mathrm{~mL}$ sterile water and vortexed at high speed to re-suspend the bacteria. To eliminate non-Legionella organisms during this selective growth process, $1 \mathrm{~mL}$ of the sample was pretreated with acidified potassium chloride $(0.2 \mathrm{M} \mathrm{KCl}-\mathrm{HCl}$ reagent; $\mathrm{pH}=2.2)$ for 15 minutes at room temperature. A $0.1 \mathrm{~mL}$ aliquot of the mixture was spread-plated on BCYE agar supplemented with GVPA (Oxoid) and a Legionella agar enrichment (BD Difco, Sparks, $\mathrm{MD})$. The plates were incubated at $36.5^{\circ} \mathrm{C}$ with $2.5 \% \mathrm{CO}_{2}$ and $94 \%$ relative humidity. Growth on the plates was monitored for up to 10 days.

DNA was extracted from an aliquot of the biofilm suspension using the QIAamp ${ }^{\circledR}$ Circulating kit (Qiagen) as specified by the manufacturer. DNA was eluted with water (final volume of $50 \mu \mathrm{L}$ ) and frozen $\left(-20^{\circ} \mathrm{C}\right)$ until qPCR. Amplification was conducted targeting the variable 23S-5S gene using primers ISR-F 5'- TGAAGCCCGTTGAAGACTAC-3' and ISR-R 5'-

GGAAGCCTCACACTATCAT-3' described by Grattard et al. (2006) synthesized by TIB MolBiol LLC (Adelphia, NJ). The number of copies were quantified with a G-Box synthesized by Integrated DNA Technologies, Iowa. PCR was conducted by a LightCycler 480 (Roche Diagnostics, Indianapolis, IN) in $20 \mu \mathrm{L}$ aliquots through 35 cycles of denaturation $\left(15 \mathrm{~s}\right.$ at $\left.94^{\circ} \mathrm{C}\right)$, annealing $\left(25 \mathrm{~s}\right.$ at $\left.55^{\circ} \mathrm{C}\right)$ and extension $\left(25 \mathrm{~s}\right.$ at $\left.72^{\circ} \mathrm{C}\right)$.

All PCR-positive products were examined on a gel to confirm the expected size of 300 base pairs. Because most bands on the gel were very faint (indicating low concentrations of the target DNA), the PCR products were re-amplified and then sequenced by TIB MioBiol LLC using the same type of set of primers. BLAST searches were performed on all valid sequences using the National Center for Biotechnology Information database (www.ncbi.nlm.nih.gov) to determine their identity. 


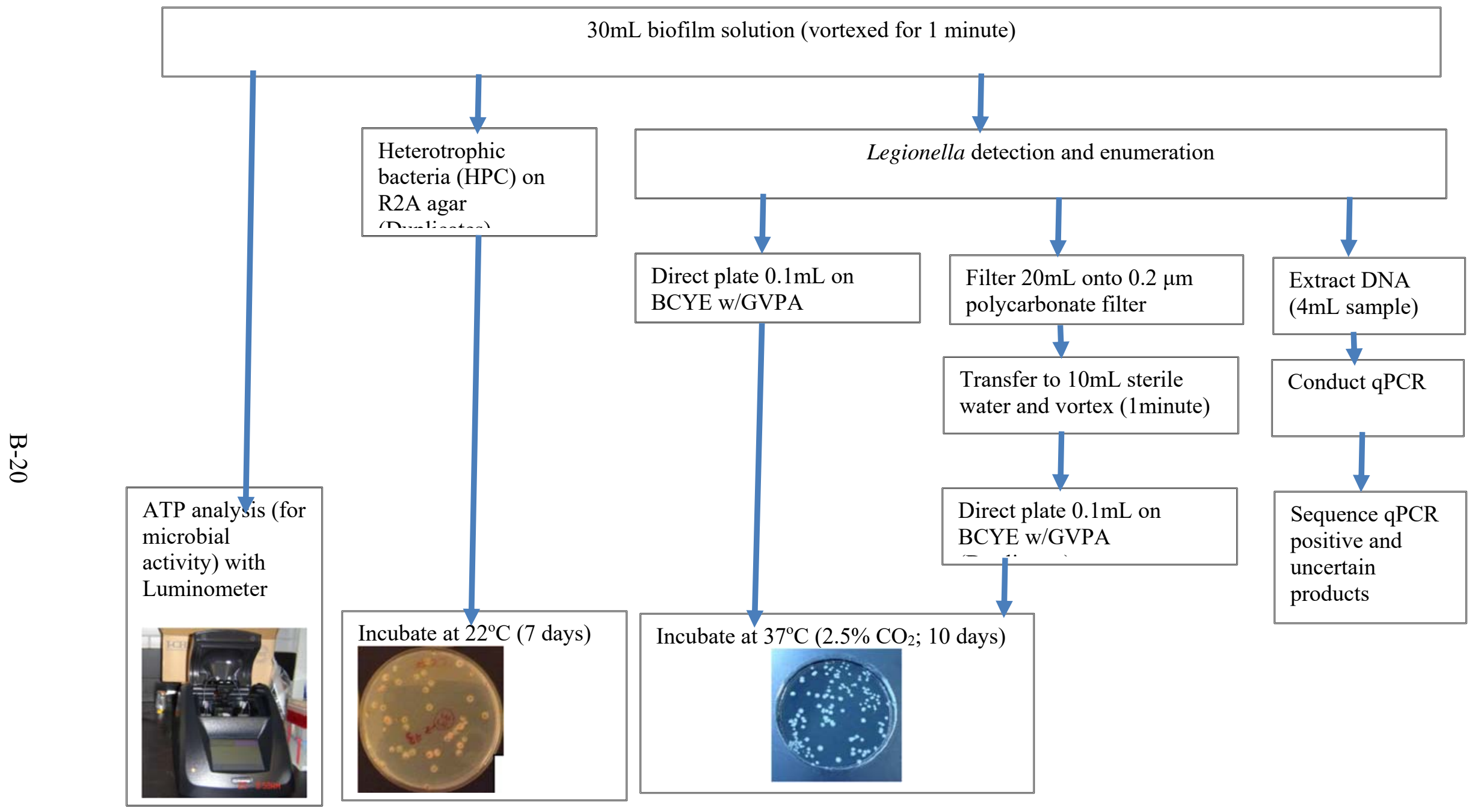

Figure A-3. Sample processing and workflow during the second testing phase 


\section{Model Simulation of Water Temperature Increase in Distribution}

The above laboratory tests were conducted to evaluate water quality impact after a single pass through the heat exchanger. The follow up question was how re-injecting the heat exchanger effluent to the distribution system would impact distribution water temperature. The increased temperature in the heat exchanger effluent would dissipate via dilution and diffusion with ambient distribution environment, after re-injecting to the distribution system. It is important to prevent or minimize the heated effluent recirculating to the suction side of the heat exchanger, which may cause heat build-up and eventually deteriorate water temperature quality.

To address these questions, existing system's hydraulic model was used to simulate the dissipation of the increased temperature from the heat exchange effluent. The model was last updated and calibrated using WaterGEMS Connect (Bentley - Watertown, CT) by a consultant Mott MacDonald in 2016 (model build report available upon request). A project site map and a screenshot of the modeling program are presented in Figure A-4. The heat exchanger was modeled as a flow controlled valve and a pump with a flow setting of $300 \mathrm{gpm}$. The increased temperature was set at $2.91^{\circ} \mathrm{C}$ based on the average temperature increase observed at the facility in May to October 2017. The influent of the heat exchanger was simulated at the 12-inch main on Horton Avenue, while the discharge effluent was simulated on the 6inch main on Trafalgar Square. A total of about 520-feet 6-inch main was assumed to be installed to take water from Horton Avenue, through the heat exchanger, and then discharge at Trafalgar Square. 


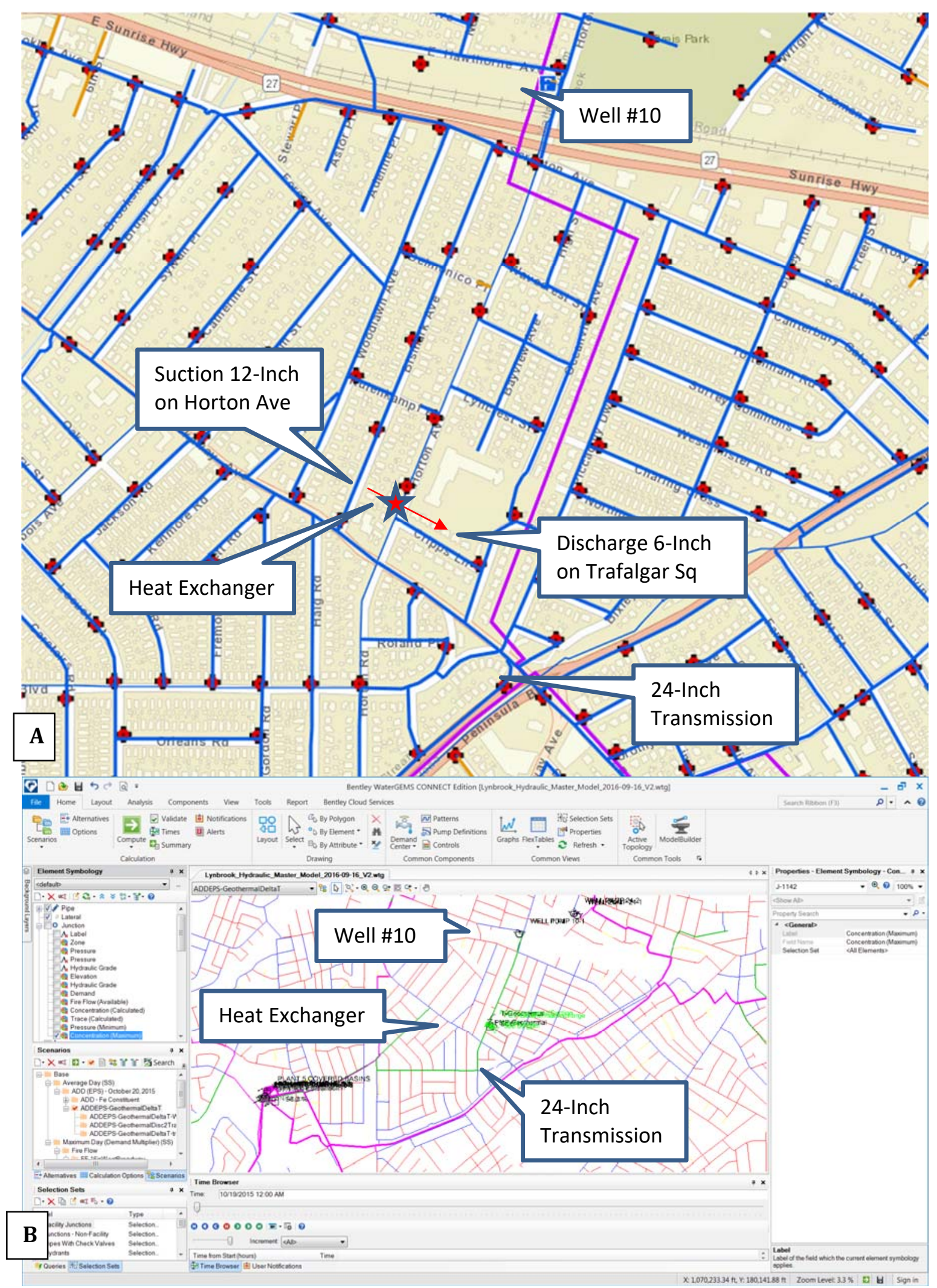

Figure A-4. Project site map (A) and model representation of the heat exchanger and the distribution system (B) 
Dissipation of increased temperature is mainly through dilution and diffusion with the ambient distribution environment. To simulate diffusion, a first-order decay model was assumed with a decay constant set at $-3.0^{\circ} \mathrm{C} /$ day, i.e., increased temperature drops to about half after four (4) hours traveling within the distribution system. This was considered low to be conservative, assuming minimal heat diffusion within the distribution system. The actual heat diffusion in distribution systems can be highly variable depending on pipe materials, pipe depth, soil conditions, and groundwater levels. The dilution of the increased temperature via mixing with distribution water depends on system hydraulics near the suction and discharge side of the heat exchanger. The following scenarios were simulated to evaluate the impact of different system conditions on dilution/mixing:

1. Baseline - existing average day demand (ADD) conditions ( 27MGD) with Well 10 offline;

2. Existing maximum day demand (MDD) conditions ( 48MGD) with Well 10 offline;

3. Existing ADD conditions ( 27MGD) with Well 10 online;

4. Existing ADD conditions ( 27MGD), Well 10 offline, and heat exchanger effluent discharge to the 24-inch transmission on Peninsula Blvd and Rockaway Ave. 


\title{
Kendra F. Morris Email communication to Ellen D. Smith, February 19, 2018.
}

\author{
From: $\quad$ Kendra Morris $<$ Kendra.Morris@amwater.com> \\ Sent: \\ To: \\ Monday, February 19, 2018 7:58 PM \\ Cc: \\ Smith, Ellen D. \\ Subject: \\ Liu, Xiaobing; Ben D Stanford; Patrick K Jjemba; Don Wieczenski \\ FW: American Water NY Geothermal Pilot - Draft Report Comments
}

Ellen,

Please see the responses to your two questions below. We are happy to get on the phone to discuss further.

1. Question: What was the methodology used on the quantitative PCR test? Was this a commercially available product? How was the base qPCR done?

Response: The PCR protocol was not from a commercial kit but rather conducted using published sequences targeting the variable 23S-5S gene using primers ISR-F 5'-

TGAAGCCCGTTGAAGACTAC-3' and ISR-R 5'- GGAAGCCTCACACTATCAT-3' described by Grattard et al. (2006). The quantification (i.e., qPCR) was based on the complete sequence of Legionella pneumophila strain Philadelphia-1 (NCBI GenBank: CP013742.1) in a synthesized genetic block (G-block) whose sequence is shown below. Concentration of this 336 bases g-block stock contained $2.76 \times 10^{10}$ copies (see conversion at $\mathrm{http}: / /$ cels.uri.edu/gsc/cndna.html). Tenfold dilutions of the G-block were loaded into triplicate wells F10,F11,F12 (0.1ng/uL), G1,G2,G3 (0.01ng/uL), G4,G5,G6 (0.001ng/uL), G7,G8,G9 (0.0001ng/uL), and G10,G11,G12 $(0.00001 \mathrm{ng} / \mathrm{uL})$ and provided the standard curve used to calculate the number of copies in actual samples loaded in rows A through E. Wells F1,F2,F3 had DNA from a known Legionella strain (i.e., positive control).

\begin{tabular}{|c|c|c|c|c|c|c|c|c|c|c|c|c|c|c|c|c|c|c|c|c|c|c|}
\hline \multicolumn{5}{|c|}{ Name - L.p_STD } & \multicolumn{8}{|c|}{ Customer Name - Williom Johnson } & \multicolumn{7}{|c|}{ gBlocks" Gene Frogments } & \multicolumn{3}{|c|}{336 bose poir } \\
\hline $5^{\prime}-$ & cec & $\operatorname{TCC}$ & $\mathrm{crc}$ & AAG & ATC & $A G:$ & TrF & $\operatorname{ccc}$ & ATC & AAG & $\operatorname{ccc}$ & GT: & GAA & GAC & TAC & GAC GTI & GAT & AGC & CAA & CGT & GTG & GAA \\
\hline $\operatorname{ccs}$ & CAC & TAA & TaC & GTG & NAG & $\operatorname{ctA}$ & ACT & TOT & ACF & AAT & too & etg & Aะร & ore & TTO & ACC ATA & TAA & $\mathrm{tCz}$ & GAO & TAA & $\operatorname{ctT}$ & CAG \\
\hline AAT & ATC & ATA & 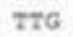 & ATT & TGT & ATA & $\mathrm{cct}$ & GAT & AAG & รAT & CGT & GTA & AAC & TCT & anc & TCI TRA & CCA & MAC & Crg & TCS & ctT & AaT \\
\hline NAN & $\operatorname{ccs}$ & ATC & ANA & $\operatorname{Gcc}$ & $\operatorname{TCA}$ & 607 & NAA & cen & oTt & $7 \pi$ & cto & $\operatorname{cco}$ & ACz & ATA & GCO & AT: TGG & anc & cac & $\operatorname{cto}$ & ATA & CCA & tes \\
\hline $\operatorname{CCA}$ & $A C T$ & CAG & AAG & TCA & AAC & ATT & $\mathrm{TCC}$ & $\operatorname{ccc}$ & $\operatorname{ccA}$ & AtC & ATA & GTG & TCA & $\operatorname{coc}$ & TIC & cre -3 , & & & & & & \\
\hline
\end{tabular}

2. Question: On Figure 4 DNA amplification with primers (page 7): What were rows $F, G$ and $H$ ? For row $\mathrm{F}$, why are there negative results for the positive control sample?

\section{Response:}

F1,F2,F3 had DNA from a Legionella strain (Positive control)

F4,F5,F6 had primers (i.e., everything needed for PCR) but NO DNA added (Negative control)

F7,F8,F9 did not have any sample or primers (i.e., were empty)

F10,F11,F12 had the highest concentration of G-block (see response to \#1 above)

Row G (other G-block dilutions; see contents outlined in response to \#1 above)

Row $\mathrm{H}$ did not contain any samples or primers (i.e., all wells in row $\mathrm{H}$ were empty)

Regards,

Kendra

Kendra F Morris

O 856.359.2091 |C 609.315.5079 | Kendra.Morris@amwater.com 